Magnetic Separation News, 1985, Vol. 2, pp. $1-48$

$0731-3632 / 85 / 0201-0001 \$ 25.00 / 0$

(C) 1985 Gordon and Breach, Science Publishers, Inc. and OPA Ltd.

Printed in the United Kingdom

THE MAGNETIC BENEFICIATION OF COAL

S.E. MALE

Central Electricity Generating Board, CERL, Kelvin Avenue, Leatherhead, Surrey, KT22 7SE, U.K.

Abstract The magnetic demineralization of coal can produce a fuel containing lower levels of sulphur and ash forming minerals. The ability of the magnetic separation technique to process material over a wide range of particle sizes $(1-1000 \mu \mathrm{m})$ and to operate on either liquid or gaseous feed enables a number of possible coal processing applications. These range from dry desulphurization of power station pulverized fuel to the cleaning of solvent refined coals. This article reviews work on the development of magnetic separation as applied to coal processing.

\title{
INTRODUCTION
}

Coal is a sedimentary rock formed from plant derived organic remains plus some non-organic material. The combustible material is the organic or carbonaceous part of the coal. By far the most important use of coal is as a pulverized fuel to raise highpressure, high-temperature steam for the generation of electricity. The coal contains inorganic materials, the behaviour and effects of which have to be coped with both inside and, subsequently, outside the power station. They can, for example, cause wear to milling and handling equipment while in recent years the impact on the environment of both solid and gaseous discharges from power stations has received particular attention. One of these gaseous discharges is sulphur dioxide.

In the UK the Central Electricity Generating Board have a "tall stack" policy to ensure that its $\mathrm{SO}_{2}$ emissions are sufficiently well dispersed for local ground level concentrations to be maintained within acceptable limits. However, 
international concern regarding the environmental impact of "acid rain" has led to proposals for restricting $\mathrm{SO}_{2}$ emission levels within the EEC ${ }^{1}$. Germany, Denmark and Holland have national limits both on fuel sulphur content and $\mathrm{SO}_{2}$ emission. At present there is no requirement to 1 imit $\mathrm{SO}_{2}$ emission from UK power stations but the CEGB is carrying out extensive investigations of the various options which would be open if controls were to be applied in the future. In the USA legislation ${ }^{2}$ enacted in 1970 set $\mathrm{SO}_{2}$ emission limits of $500 \mathrm{~g} / \mathrm{GJ}$ for new power plant. This standard has since been reduced to $250 \mathrm{~g} / \mathrm{GJ}$ and in addition there is a mandatory requirement to incorporate flue gas desulphurization (FGD) to some degree even if the plant is burning low sulphur fuel which could have achieved the standard without FGD. (For relationship between sulphur content of fuel and emission levels see Appendix 1). It was these environmental considerations which gave the initial impetus for the renewed interest in magnetic separation of inorganic material from coal, although the recovery of waste coal and the treatment of solvent refined and liquefied coals are areas in which magnetic separation may also prove attractive.

Coals generally contain 1 to 5 percent of sulphur, about a third of which is carbonaceous in form and is referred to as organic sulphur. The rest is mineral sulphur consisting almost entirely of finely divided crystals of iron pyrite. The organic sulphur is closely bonded to the coal so that its removal is not possible without large scale chemical manipulation. Consequently, virtually all the work on the desulphurization of coal has been directed towards the removal of inorganic sulphur. Various techniques have been investigated for the extraction of pyrites ranging from froth-floatation to electrostatic separation, with varying degrees of success. Magnetic separation is another option, which has been recognised as a potentially inexpensive method of desulphurization since the late fifties although it was not until 
the early seventies, with the advent of the high gradient magnetic separator (HGMS), that its technical and commercial feasibility was demonstrated.

Nevertheless, the treatment of a complex intimately mixed substance, such as coal, to remove one particular part is far from straightforward. The feed supplied to the separator contains the organic mineral-free and non-pyritic coal. It also contains magnetically polarizable free particles of mineral matter and of inorganic sulphur which can be trapped relatively easily at capture sites in the magnetic separator. Furthermore, it contains middlings comprising particles containing both organic coal and unliberated paramagnetic inorganic materials. If too high a field is used in the separator system, some of these middlings are trapped on the matrix, thus causing an important fraction of the organic coal to be included in the magnetic fraction, with a consequent reduction in the thermal yield of the system product.

To efficiently demineralize coal yet lose only the minimum amount of carbonaceous material and maintain a high process throughput is the goal of the magnetic benefication; considerable progress has been made towards this end in the last decade. It is the object of this review to discuss these developments and the issues they raise.

\section{THE CONSTITUENTS OF COAL}

Coal Petrology

Coal is a complex mixture of plant derived organic remains plus some inorganic minerals. The carbon based component is basically the combustible part and must constitute more than 50 percent by weight for the strata to be called coal. The basic constituent of the coal is termed a 'maceral' of which there are three groups, vitrinite, exinite and inertinite. Vitrinite is the most important maceral and is derived from various cellular material. Exinite consists of macerals derived from spores, cuticles, resin 


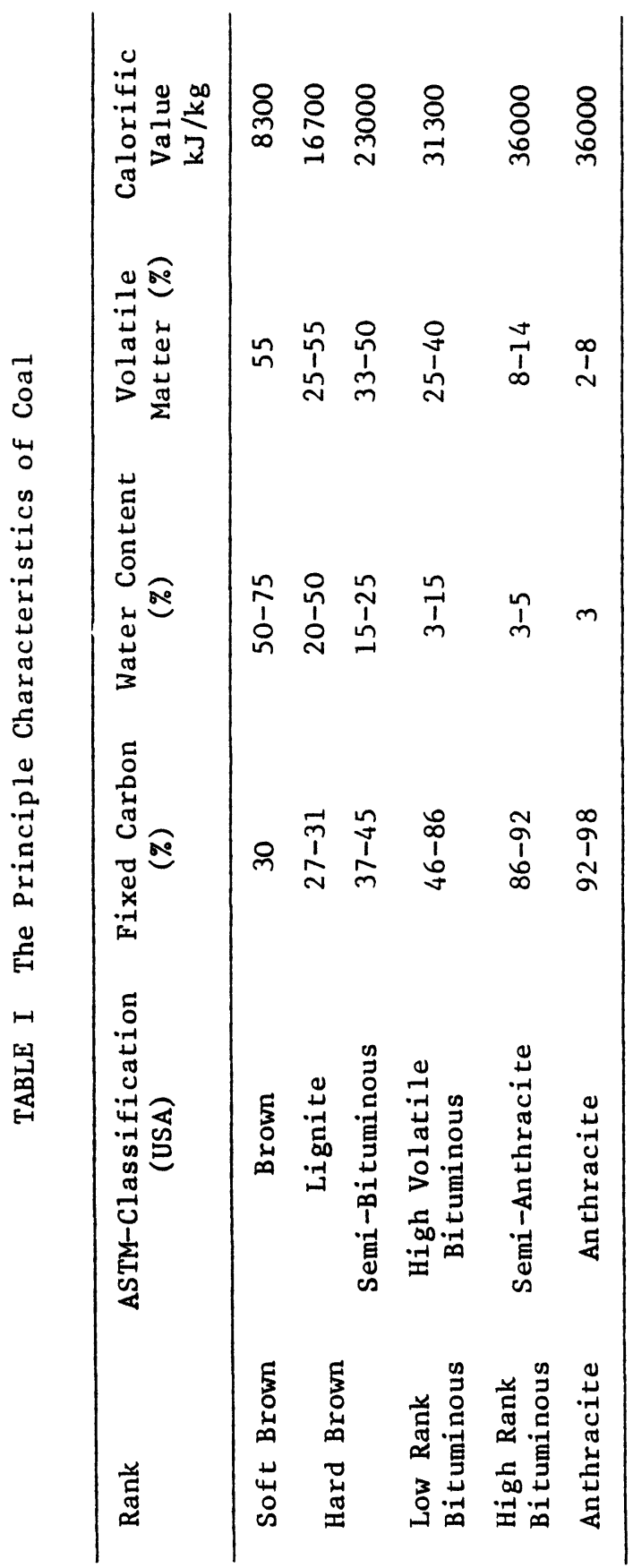


and algae. The final maceral group is inertinite, which is high in carbon and low in hydrogen and is formed from similar material to vitrinite except it has been subjected to greater oxidation during coalification. The macerals are the components of the coal and various proportions of them form the so-called microlithotypes which are the basic coal types. For example, vitrite is only found in bituminous coals and contains only vitrinite and inertinite. Complete nomenclature of coal petrology can be found in $\mathrm{Stach}^{3}$.

A particular coal strata can be classified according to the amount of fixed carbon present (the carbon left after the coal has been heated to a specified temperature). The amount of fixed carbon determines the rank of the coal. Each coal rank is formed from various microlithotypes. Table 1 gives the rank stages and various other parameters.

Every continent of the world including Antartica, contains coal with up to 70 countries having successful mining operation. Most of the identified coal reserves occur in the Northern Hemisphere with the USA, the Soviet Union and China accounting for about 80 percent. As the majority of magnetic beneficiation work has been on United States coals a brief description of that country's coal fields will be useful. The main coal basins are the Appalachian, Illinois, Western Interior and Rocky Mountains. The Appalachian basin runs from Pennsylvania (this includes the $8000 \mathrm{~km}^{2}$ Pittsburgh seam) to Alabama and produces approximately 75 percent of the USA output. The coal is mainly high-rank bituminous. Second in importance is the Illinois basin which includes Indiana and part of Western Kentucky. This region yields about 20 percent of the country's production. The coal is of the high-volatile bituminous type. The other areas account for the remainder.

Mineral Impurities in Coal

The minerals occurring in coal can be divided into those that form 
ash and those that form sulphur compounds. These groups can also be divided into 'organic' impurities that are structurally part of the coal (and hence cannot be removed by physical processing) and 'inorganic' impurities that occur as discrete mineral particles and form a mixture with the coal. Concentrations of sulphur in UK steam coals range from 1 to 3 wt.\% of which about one third is organic.

The ash forming minerals vary greatly but are basically mixtures of $\mathrm{SiO}_{2}$ and $\mathrm{Al}_{2} \mathrm{O}_{3}$ derived from sands, clays and shales; $\mathrm{MgO}$ and $\mathrm{CaO}$ from limestone and a number of other alkali metal oxides together with some trace elements. Even the purest coal strata contains 3 percent mineral matter and typical commercial coals 10 percent or more.

The main sulphur mineral is iron pyrite, $\mathrm{FeS}_{2}$, which is commonly found in sedimentary rocks. Other sulphides and sulphates do occur but they generally form less than 5 percent of the total sulphur. The process by which the pyrite was formed is generally believed to have occurred in three stages 4,5 . An anaerobic bacterial sulphate reduction combined with decomposition of organic sulphate to give $\mathrm{H}_{2} \mathrm{~S}$ which then reacts with iron minerals to form 'FeS' (black amorphous iron monosulphide or fine grained mackinwinite). The FeS is then transformed to $\mathrm{FeS}_{2}$ by the reaction represented by:

$\mathrm{FeS}+\mathrm{SO} \rightarrow \mathrm{FeS}_{2}$

The iron pyrite that was formed during the deposition of the coal strata is usually present as small crystals and framboids dispersed throughout the seams and is known as syngenetic pyrite. Framboids are small spherical aggregates of crystals ranging in size from 1 to $50 \mu \mathrm{m}$. The term 'framboid' comes from their external similarity in shape to raspberries (framboises). Pyrite formed after the coal, occurs in veins, along joints and cracks (possibly up to $50 \mathrm{~mm}$ or more thick) and in the form of lenses 


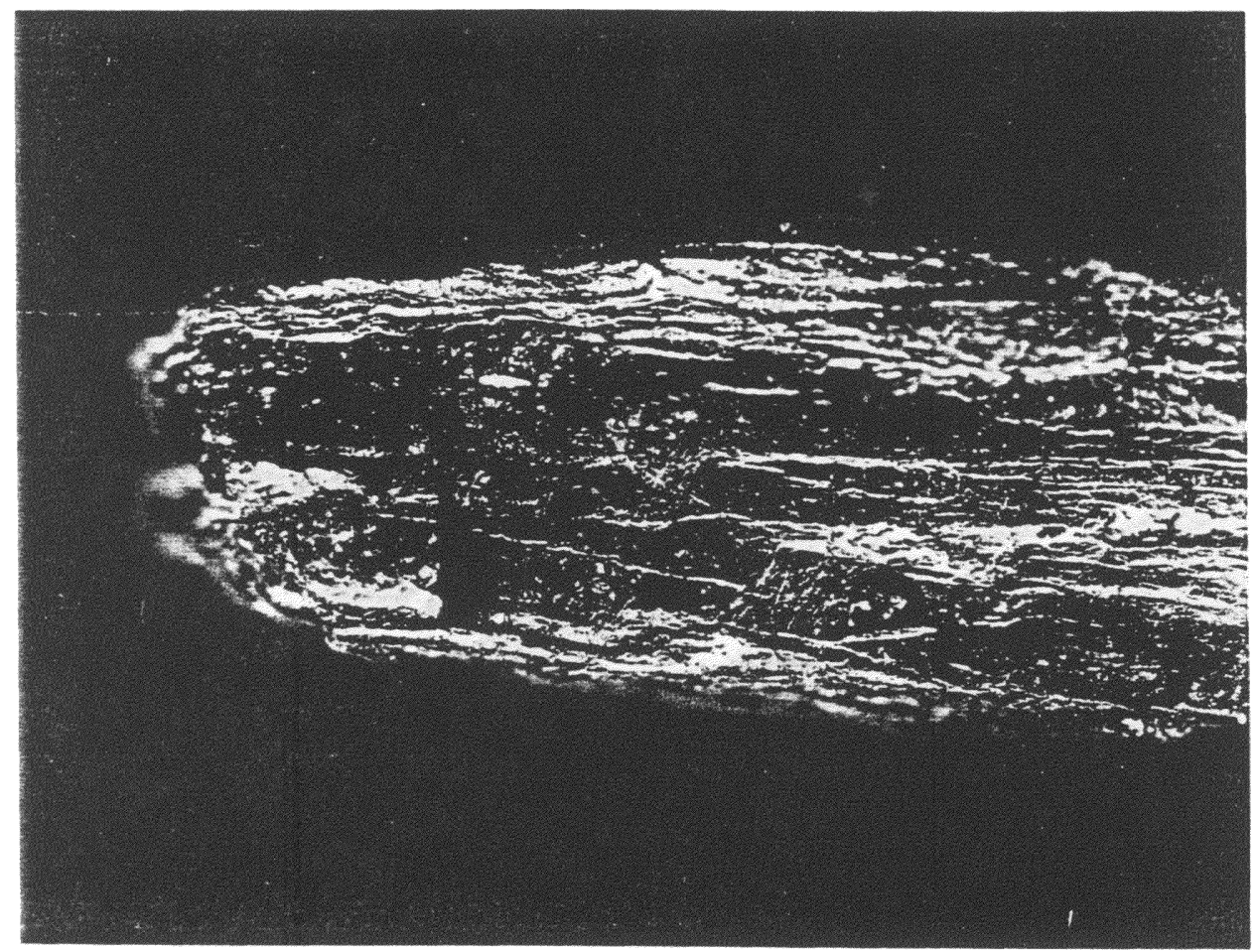

FIGURE 1 Epigenetic iron pyrite in vein-like structure (5x). Coal Field Farm North Colliery, UK. 


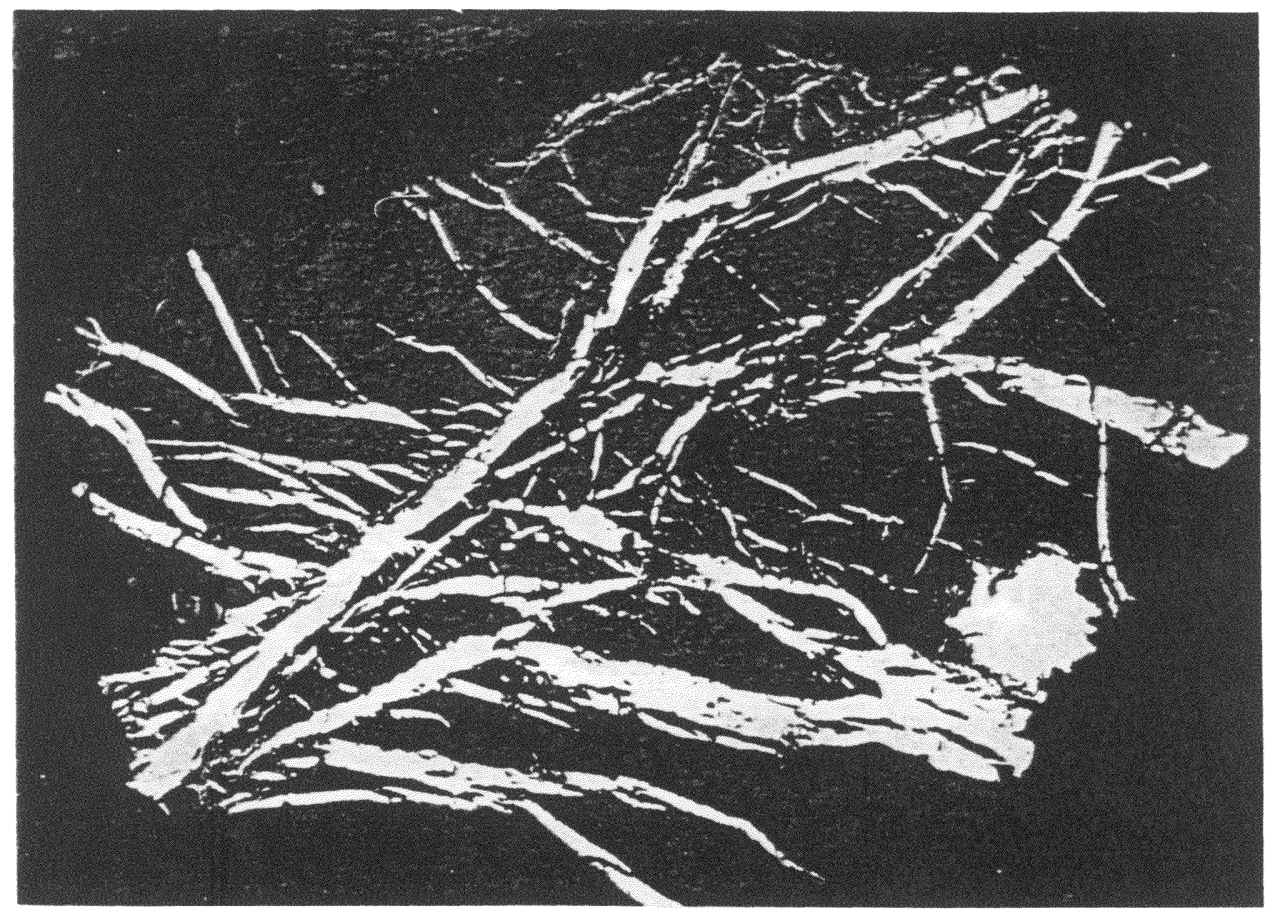

FIGURE 2 Infilling of root-like structures (100x) by iron pyrite. Coalfield Farm Colliery, UK. 
and nodules; this type of pyrite is known as epigenetic. Pyrite can also replace plant tissue in the coalification process. Fig. 1 shows epigenetic iron pyrite and Fig. 2 shows the in-filling of a root structure by iron pyrite.

The great variety of pyrite morphology highlights one important aspect of the magnetic separation of pyrite from coal, that is, the pyrite mineral must be physically separated from the coal before magnetic removal can occur. Clearly coals with mainly syngenetic pyrite will be more difficult to magnetically clean because of the smaller pyrite particle size and hence greater difficulty in liberation.

THE MAGNETIC STRUCTURE AND PROPERTIES OF THE IRON-SULPHIDE

The iron-sulphur alloy system is complex and contains many compounds, most of which have a greater magnetic susceptibility than iron pyrite, $\mathrm{FeS}_{2}$ (marcasite is a polymorph of pyrite). For example, the compound monoclinic pyrrhotite is ferrimagnetic. The phase diagram for this system is shown in Fig. 3 and the more important compounds are listed in Table 2.

The iron-sulphides are transition metal chalogenides, with a NiAs-like structure except at the sulphur rich (pyrite-marcasite) end of the phase system. The NiAs structure consists of As ${ }^{2-}$ ions in a three-dimensional hexagonal close packed arrangement, with the $\mathrm{Ni}^{3+}$ ions in the interstices. There are two types of interstices, octahedral and tetrahedral. The octahedral sites are equal in number to the $\mathrm{As}^{2-}$ ions and are fully occupied if the compound has perfect stoichiometry. The NiAs structure is found only in compounds of the transition metals in which the cations have partly filled shells. The $d-d$ bonding dominates at low temperatures. In the iron-sulphur system above $320^{\circ} \mathrm{C}$ the undistorted NiAs structure occurs over a wide range of composition. 


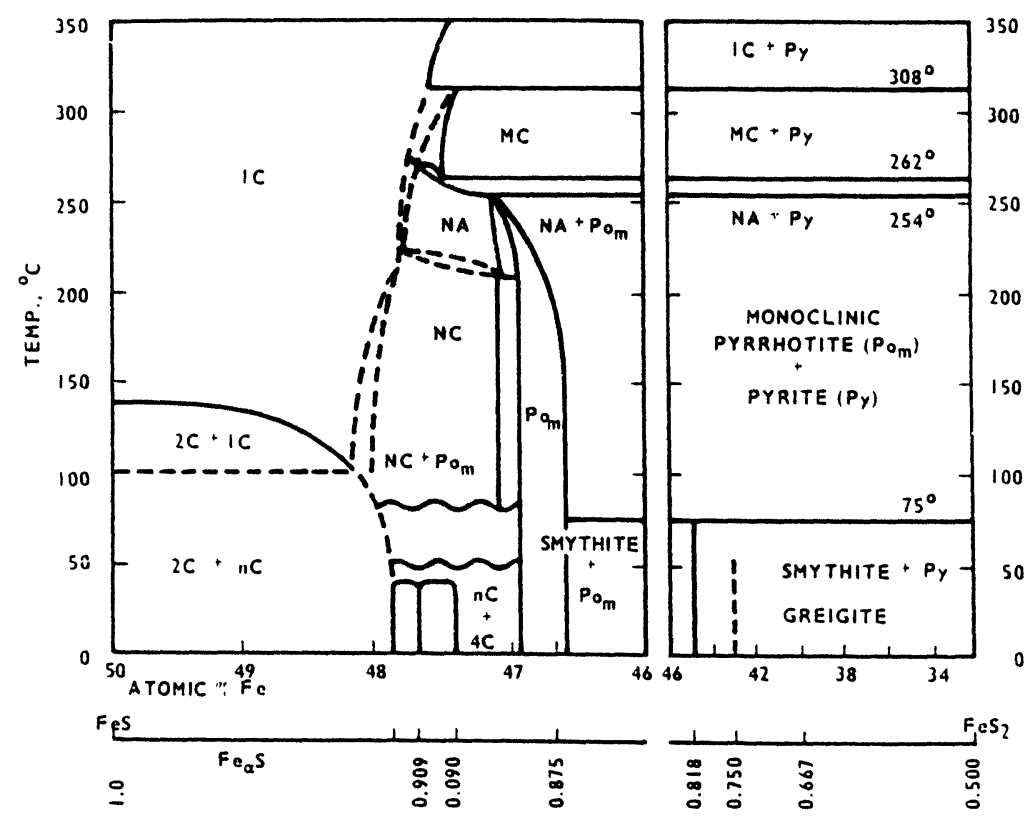

FIGURE 3 The equilibrium phase diagram of the iron-sulphur sys tem ${ }^{9}$

TABLE 2 The compounds of the iron-sulphur phase system

\begin{tabular}{llcc}
\hline \multicolumn{1}{c}{ Mineral } & $\begin{array}{c}\text { Chemical } \\
\text { Formula }\end{array}$ & $\begin{array}{c}\text { Atomic } \\
\% \mathrm{Fe}\end{array}$ & $\begin{array}{c}\text { Atomic Ratio } \\
\mathrm{Fe}_{\mathrm{x}} \mathrm{S}\end{array}$ \\
\hline Troilite & $\mathrm{FeS}$ & 50.00 & 1.00 \\
& $\mathrm{Fe}_{11} \mathrm{~S}_{12}$ & 47.83 & 0.92 \\
Hexagonal pyrrhotite & $\mathrm{Fe}_{10} \mathrm{~S}_{11}$ & 47.62 & 0.91 \\
& $\mathrm{FegS}_{10}$ & 47.37 & 0.90 \\
Monoclinic pyrrhotite & $\mathrm{Fe}_{7} \mathrm{~S}_{8}$ & 46.67 & 0.88 \\
Smythite & $\mathrm{Fe}_{9} \mathrm{~S}_{11}$ & 45.00 & 0.82 \\
Greigite & $\mathrm{Fe}_{3} \mathrm{~S}_{4}$ & 42.86 & 0.75 \\
Gamma FeS & $\mathrm{Fe}_{2} \mathrm{~S}_{3}$ & 40.00 & 0.67 \\
Pyrite, marcasite & $\mathrm{FeS}_{2}$ & 33.33 & 0.50 \\
\hline
\end{tabular}


THE MAGNETIC BENEFICIATION OF COAL

TABLE 3 The magnetic properties of the constituents of coal

\begin{tabular}{lccc}
\hline \multicolumn{1}{c}{ Compounds } & $\begin{array}{c}\text { Chemical } \\
\text { Formula }\end{array}$ & $\begin{array}{c}\text { Magnetic Susceptibility } \\
\left(\mathrm{kg}^{-1} \times 10^{8}\right)\end{array}$ & Ref \\
\hline $\begin{array}{l}\text { Pyrite } \\
\begin{array}{l}\text { Monoclinic } \\
\text { pyrrhotite }\end{array}\end{array}$ & $\mathrm{FeS}_{2}$ & 0.34 & 8,10 \\
Limonite & $\mathrm{Fe}_{7} \mathrm{Fe}_{8} \mathrm{O}_{3} \mathrm{H}_{2} \mathrm{O}$ & Ferrimagnetic & 7 \\
Siderite & $\mathrm{FeCO}_{3}$ & 71.6 & 11,12 \\
Ferrous sulphate & $\mathrm{FeSO}_{4}$ & 417.0 & 11,12 \\
Calcite & $\mathrm{CaCO}_{3}$ & 126 & 11,12 \\
Limestone & - & 1.2 & 11,12 \\
Shale & - & 4.7 & 11,12 \\
$\begin{array}{l}\text { Sandstone } \\
\text { Coal (mineral } \\
\text { free) }\end{array}$ & - & $40-60$ & 11,12 \\
\hline
\end{tabular}

When the temperature is reduced to a value which permits the d-electron bonding to exert control over the structure, distortion occurs. This leads to the formation of ordered vacancy structures in pyrrhotite and of triangular $\mathrm{Fe}_{3}$ clusters in troilite. At the sulphur rich end of the phase system the main structural feature is a strong sulphur-sulphur bond, giving $\mathrm{s}_{2}{ }^{2-}$ groupings. In pyrite the iron atoms are in a face-centred cubic arrangement with the $\mathrm{S}_{2}{ }^{2-}$ groups located on the cube diagonals. This effectively gives an octahedral group of iron atoms around each pair of sulphur atoms 6,7 .

In an octahedral crystal field the ferrous $\left(\mathrm{Fe}^{2+}\right)$ ions $d$-orbitals are non-degenerate and split into two levels $t_{2 g}$ and $e_{g}$. The electronic ground state of the ion depends on the balance between the energy to be gained by having electrons in different orbitals (thus maximizing the exchange, J. and Coulomb, V, energies) and the energy to be gained by having all the electrons 
in the lowest set of orbitals (the crystal field energy, $\Delta$ ). Two limiting cases can be distinguished $\Delta<J+V$ (the 'high spin' case) and $\Delta>J+V$ (the 'low spin' case). In the low spin case Hund's rules are not obeyed and it is energetically favourable for the electrons to go into the lowest available orbitals. This is the case in the $\mathrm{FeS}_{2}$ where the $\mathrm{S}_{2}{ }^{2-}$ ions give a very strong crystal field term (i.e. $\Delta>J+V$ ). The electronic configuration of iron is therefore $\mathrm{Fe}^{2+}: \mathrm{T}_{2}{ }^{6} \mathrm{e}_{\mathrm{g}}{ }^{0}$ giving a ground state orbital and spin singlet. Nevertheless a small temperature independent paramagnetism is observed which derives from the mixing of orbital ground and excited states. This is known as Van Vleck paramagnetism. However, the largest contribution to the paramagnetism is due to impurity atoms such as $\mathrm{Co}$ and $\mathrm{Ni}$ which have a moment in the pyrite lattice ${ }^{8}$.

In the cation deficient $\left(\square_{\delta} F e_{1-\delta} S\right)$ region there are a number of compounds, one of which pyrrhotite is particularly important and for simplicity all compounds in the range FeS to $\mathrm{Fe}_{1} \mathrm{~S}_{8}$ will be referred to generally as pyrrhotite. The nomenclature for the pyrrhotites is given in Appendix 2. The crystallographic structure of $\mathrm{Fe}_{1-\delta} \mathrm{S}$ is that of a NiAs. The crystal field is such that the iron atoms are in a high spin state, that is Hund's rules are obeyed and $S=2$. Generally the cationanion-cation exchange interaction leads to antiferromagnetism in the pyrrhotites. However, vacancy ordering and interstitial ions (in the trigonal-bipyramidal interstices) complicate the situation. Of the stable pyrrhotites only monoclinic pyrrhotite (4C) has a spontaneous moment at room temperature. This compound can be thought of as a defect structure antiferromagnet. All the iron spins within a given layer are parrallel and in the next layer anti-parallel but because the vacancies within the structure condense on to alternate layers below the Néel temperature the compound has a spontaneous moment. Troilite (2C) and hexagonal pyrrhotite (5C) do not have this property at room 
temperature. Detailed reviews of the iron sulphide system have been written by Ward ${ }^{6}$ and Power and Fine ${ }^{9}$.

As iron pyrite is a ground state singlet the inherent paramagnetic moment is small and even with the additional effect of impurities the magnetic susceptibility is still only in the region 0.3 to $1 \times 10^{-8} \mathrm{~kg}^{-1}$ at room temperature. For comparison a list of the magnetic susceptibilities of constituents of coal are given in Table 3 .

Coal and iron pyrite have roughly the same value of susceptibility but with opposite signs (coal is diamagnetic). Both susceptibilities are very small, and considering the high throughputs required for a coal processing system, this has been a major obstacle to the magnetic desulphurization of coal. A number of points, however, should be made about the magnetic susceptibility of pyrite. The values only apply to large (>mm) samples where the surface area is small compared to the volume of the crystal. Pyrite is only stable in the absence of air (as in coal strata) and hence any handling, weathering or crushing will affect, either by oxidation or low temperature phase transformation, the surface structure and properties. Clearly the smaller the pyrite particle size the greater this effect will be. Whether the pyrite is epi-or syngenetic may therefore affect not only the liberation but also the relative susceptibility 8,10 .

\section{THE MAGNETIC BENEFICIATION OF COAL}

\section{Objectives}

Before discussing in detail the various studies on the application of magnetic separation to coal it will be useful to list the pre-requisities that a magnetic separator must try to fulfil if it is to be an economically viable system.

(a) The iron pyrite must be removed with as high efficiency as possible as even with 100 percent removal the organic sulphur would still be present. Combined with this the 
amount of combustible matter lost in the separation process should be low, as even a 10 percent loss could make magnetic desulphurization prior to combustion economically unattractive. Furthermore, the removal efficiency for ash should be good because the greater the ash content of the coal the higher the cost of mills and consequent fly ash removal.

(b) Most coal users have high volume throughputs (for example, a 2000 MW power station burns about 750 tons of coal per hour) and therefore the magnetic separator must be able to deal with large quantities of material whilst maintaining high removal efficiency. Probably the minimum throughput for a commercial separator would be between 50 and 100 tons per hour.

(c) Dry (or quasi-dry) operation is essential for the desulphurization of pulverized coal as dewatering fine coal is technically difficult and very expensive. If, however, combustion of coal-water slurries become acceptable wet fine coal processing could be a favoured technique.

\section{Historic Perspective}

The recovery of iron pyrite from UK coals has had a long and successful history culminating in World War 2 when over 100,000 tons were produced. This was a major contribution to the vital sulphur supplies for the chemical and metallurgical industries. About 40 percent of the pyrite was produced by hand selection of large modules after a preliminary screening of the raw coal at around $100 \mathrm{~mm}$. This was only possible on coal from high sulphur seams where the pyrite nodules were large. Additional production came from the processing of high sulphur fines from washeries using purpose built conventional plant.

With the high cost of manpower and the increased production of elemental sulphur, pyrite is no longer recovered from coal for sulphur production. Interest now lies in the utilization of the coal and the removal of pyrite as an unwanted impurity. New 
techniques for coal desulphurization have been sought for a number of years as hand picking is clearly impractical:

Studies in the late fifties and early sixties $14-18$ used low gradient magnetic separators which in some cases were just horeshoe magnets. Pure iron pyrite could not be removed by this method because of its very low susceptibility. Therefore much attention was given to the magnetic enhancement of the pyritic component. Unfortunately the results were unpredictable and often contradictory. For example, Yurouski and Remesnikov 14 steam-air treated some Soviet coals at temperatures ranging from 120 to $360^{\circ} \mathrm{C}$ for periods between 15 seconds and 5 minutes. By using a drum type separator they were able to reduce the sulphur content, typically, from 2.44 to 1.6 percent using a preheat of $320^{\circ} \mathrm{C}$ for 15 seconds. They stated that the possible mineral contaminants of magnetite, ferric and ferrous sulphate. Kester 17 in the USA attempted similar experiments with Upper Freeport bed coal. He steam treated the coal for 5 to 10 minutes at temperatures ranging from 175 to $280^{\circ} \mathrm{C}$ and at various air to steam ratios. The results were disappointing and Kester concluded that better coal quality as well as separation efficiency were obtained by magnetic beneficiation of raw untreated coals. Work by Ergun and Bean 18 for the US Bureau if Mines came to essentially the same conclusion that, 'contrary to earlier experiments heat (air-steam) treatmemt did not prove to be beneficial in most cases', but they did find that dry heat treatment above $300^{\circ} \mathrm{C}$ improved the separation to a limited extent. No attempts were made to heat above $400^{\circ} \mathrm{C}$ as they feared decomposition of the coal.

One of the most encouraging of the early studies was that by Kester, Leonard and Wilson ${ }^{12}$ on dry pulverised coal from West Virginia. They used an isodynamic separator operating at $1.18 \mathrm{~T}$ in the vibrating shute mode. The coals were pulverized to pass through a 48 Tyler mesh $(-300 \mu \mathrm{m})$. The tests on the $-0+48$ fraction were inconclusive and only $-48+200$ mesh $(300-74 \mu \mathrm{m})$ 
size fractions were reported. It should, however, be noted that coal pulverized to -48 mesh would have a mean diameter for the weight distribution of about 30-70 $\mu \mathrm{m}$ and therefore removal of the $-200(74 \mu \mathrm{m})$ mesh fraction would involve a loss of up to 70 percent of the raw coal. Nevertheless, results for the $-48+200$ mesh fraction were good and are summarized in Table 4.

TABLE 4 The absolute removal efficiency (yield $\times$ (percent in product) $\div$ (percent in feed)) for Sulphur and Ash from Kester et al. 12

\begin{tabular}{lccccc}
\hline Coal Sample & Ash & \multicolumn{4}{c}{$\begin{array}{c}\text { Percent Removal of } \\
\text { Sulphur Forms }\end{array}$} \\
\hline & & Pyritic & Organic & Sulphate & Total \\
\hline Upper Freepoort & 39 & 83 & 29 & 74 & 62 \\
Redstone & 26 & 54 & 5 & 62 & 29 \\
Sewickley & 45 & 65 & 17 & 75 & 42 \\
Pittsburgh & 42 & 66 & 25 & 81 & 60 \\
\hline
\end{tabular}

These early studies showed that given the right mineral liberation and magnetic conditions, magnetic beneficiation of pulverized coal was possible. The problem was that the separators were uneconomic to scale to size at which adequate throughputs could be achieved. Two developments changed this situation, the invention of $\mathrm{Kolm}^{19}$ and Marston 20 of the high gradient magnetic separator (HGMS) and the application of superconducting magnets to open gradient magnetic separators 21 .

HIGH GRADIENT MAGNETIC SEPARATION (HGMS)

Wet beneficiation of coal

(a) American Studies

The first major work on the desulphurization of coal by HGMS was by Trindade 22,23 using prewash coal, ground to various sizes from 
the Brazilian Sideropolis field ( $30 \mathrm{wt}$. percent mineral matter and 2 to 3 percent sulphur, mainly pyritic). The slurries were prepared by mixing known amounts of coal, of a known size distribution, water and for the finer coal wetting agents to give solid concentrations in the range 1.5 to 2.9 wt. percent. The magnetic separator was a solenoid packed with stainless steel wool of diameter $100 \mu \mathrm{m}$ to a density between 1 and 13 vol. percent. The mangetic field at the centre of the solenoid bore was $2.0 \mathrm{~T}$. Trindade states that the magnetic susceptibility of the pyritic particles was $3.2 \times 10^{-7} \mathrm{~kg}^{-1}$ which is considerably higher than that of pure pyrite. However, it seems likely that the particles had some sulphate in them.

In a typical run, with a top particle size of $44 \mu \mathrm{m}$ and a slurry velocity of $20.0 \mathrm{~mm} \mathrm{~s}^{-1}$, Trindade found that the recovered product (approximately 80 percent of the feed) contained only 0.81 wt. percent of total sulphur compared with 1.32 wt. percent in the feed. The results, generally, showed that the HGMS reduced the total sulphur by 20 to $50 \mathrm{wt}$. percent and the other mineral matter by 14 to $21 \mathrm{wt}$. percent. In all the Trindade studies only single pass experiments were reported.

With the growing use in the 1970's of HGM separators in the Kaolin and mineral processing industries a number of companies in the USA (Pacific Electric Motors, Magnetic Corporation of America and Stearn Magnetics) started to produce commercial separators. Murray 24 investigated the beneficiation of some East Coast American coals using a Pacific Electric Motor's high intensity magnetic separator. The coal was from Warrick County, Indiana and the two varieties used, coal V and coal VI, had a total sulphur content of 4.63 and $4.17 \mathrm{wt}$. percent of which 2.44 and 2.20 wt. percent was inorganic. He stated that the magnetic susceptibility of the pyritic particles was $6 \times 10^{-8} \mathrm{~kg}^{-1}$, again higher than pure pyrite. 
The coal was pulverized such that approximately 99 percent of the particles would pass through a 200 mesh $(-74 \mu \mathrm{m})$ sieve. The HGMS had a cannister volume of 5 by 21 inches, a field of $2.0 \mathrm{~T}$ and was filled to a packing density of 1 percent with steel rovings. Murray found that the efficiency of the separation depended on the retention time (the length of time the slurry is in the separator's active volume). A sample of coal $\mathrm{V}$ had its total sulphur content reduced from 4.6 to 3.8 w.t. percent for a 30 second and to 3.5 wt. percent for a 60 second retention time. If the slurry was recycled instead of increasing the retention time the efficiency of separation increased. For example, two passes each with a retention time of 30 seconds reduced the total sulphur content from 4.6 to 3.1 wt. percent which compares favourably with the results for a 60 second retention time. Murray's results appear to indicate that multiple pass mode of operation is the most efficient and typically he found that for three passes the reduction in inorganic sulphur for coal $V$ was up to 67 wt. percent and for VI, 85 wt. percent. In fact the results show that the separator has the same performance in all modes as changing the retention time effectively changes the linear velocity and increasing the passes changes the effective matrix bed length, L. As the separator performance is proportional to $\mathrm{L} / \mathrm{V})^{1 / 3}$ where $\mathrm{V}$ is the linear velocity through the matrix the results represent the same performance when both these parameters are adjusted.

A pilot-scale study, again using a Pacific Electric Motor's separator, was made by Lin et al. ${ }^{25}$ to optimize the parameters associated with the magnetic removal of sulphur and ash from coal slurries. They used Kentucky No, 9/14 and Illinois No. 6 coals both of which contain approximately $1.1,0.1$ and 1.85 wt. percent of pyritic, sulphate and organic sulphur and also 8.11 wt. percent ash. The following is a selection of their more important results: 
(a) The use of high coal concentrations in the slurry does not significantly change the separation efficiency. This is an important point as high coal slurry concentrations, of say around 30 wt. percent, can reduce separation costs. Recent work has shown that slurry concentrations of greater than $30 \mathrm{wt} \%$ may have some effect on performance 30 .

(b) The removal of sulphur was not noticeably affected by the packing density of the stainless steel wool matrix. Packing densities between 94 and 97 vol. percent voids were used.

(c) The magnetic susceptibility of the feed was found to be $+5.16 \times 10^{-8} \mathrm{~kg}^{-1}$ indicating the large percentage of ash present. The ash in Illinois No. 6 was mainly kaolinite $\left(\mathrm{Al}_{2} \mathrm{Si}_{2} \mathrm{O}_{5}(\mathrm{OH})_{4}\right)$ and calcite $\left(\mathrm{CaCO}_{3}\right)$ both of which are paramagnetic. The inorganic sulphur consisted of pyrites with approximately 10 percent sulphate.

(d) Recycling the tail products was shown to reduce the ash content by $64 \mathrm{wt} \%$ and the inorganic sulphur by $76.1 \mathrm{wt}$. percent. These results were obtained after the tails had been recycled three times. The coal was Kentucky No. 9/14. They concluded that the HGMS was effective in reducing the weight percent of total sulphur, ash and inorganic sulphur by as much as 40,35 and 80 wt. percent respectively while achieving a maximum recovery of 95 wt. percent.

A recent and comprehensive analysis of wet magnetic coal cleaning has been published by EPRI ${ }^{26}$. The primary objective of the work was to perform an engineering assessment of the feasibility of magnetic coal cleaning for the electric utilities. of the four projects undertaken as part of the study two used HGMS directly on water-coal slurries; Sala Magnetics Inc. used an iron cased solenoid for tests on five Eastern USA bituminous coals and Magnetic Corporation of America tested two similar coals with a superconducting HGMS. 
The Sala tests were performed on a laboratory scale HGMS (Sala Model 10-15-20) with a $10 \mathrm{~cm}$ bore and on a pilot plant scale continuous carousel. Both could be operated at fields up to $1.7 \mathrm{~T}$. The coals were slurried at concentrations ranging from 0 to $15 \mathrm{wt}$. percent coal and processed at velocities from 5 to $40 \mathrm{~mm} \mathrm{~s}^{-1}$. The optimum grind for the coal necessary to liberate the mineral matter depends on the size distribution of the mineral matter within the coal, so Sala tested a number of different grinds from 60 percent minus 200 mesh $(-74 \mu \mathrm{m})$ to 90 percent minus 200 mesh. As expected, the finer the coal grind the greater the sulphur removal. The Sala batch HGMS results are given in Table 5, these results are for runs which showed the maximum pyritic sulphur removal.

TABLE 5 Selected results from EPRI sponsored wet HGMS investigations

\begin{tabular}{lcccc}
\hline \multirow{2}{*}{ Coal } & \multicolumn{3}{c}{ Percent removal } & \begin{tabular}{c} 
Coal \\
\cline { 2 - 4 }
\end{tabular} \\
\cline { 2 - 4 } & Ash & Pyritic-S & Total-S & Recovery \\
\hline Old Ben & 24 & 49 & 25 & 69.2 \\
Canterbury & 30 & 77 & 51 & 54.4 \\
Sewickley Seam & 58 & 82 & 55 & 37.4 \\
Pittsburgh No. 8 & 28 & 66 & 33 & 70.2 \\
Delmont Mine* & 60 & 62 & 65 & 55.7 \\
\hline
\end{tabular}

* The Delmont Mine coal was precleaned at 1.6 specific gravity.

Typical inverse relationship between the product grade and recovery was reported. A sample of Delmont mine coal cleaned at 1.6 specific gravity prior to grinding was processed using the carouse 1 at a field of $1.6 \mathrm{~T}$ and flow of $10 \mathrm{~mm} \mathrm{~s}^{-1}$. The results were comparable to the batch HGMS . 
The other EPRI sponsored work investigated 01d Ben and Delmont Mine coal using a superconducting HGMS capable of producing fields up to $5.0 \mathrm{~T}$. The results were in broad agreement with the previous study showing total sulphur reduction up to 55 wt. per cent for clean coal yields of 60 percent. However, at $5.0 \mathrm{~T}$ the product recovery was generally poor ( 45 percent) and the total sulphur reduction was not greatly improved from the results at $2.0 \mathrm{~T}$.

(b) European Studies

There have been a number of recent studies in Europe looking at both Germany and UK coals. In the Netherlands, the Dutch National Coal Research Programme commissioned FDO Technische Adviseurs and Holec Nederland 27,28 to investigate the desulphurization and de-ashing of pulverized coal. Four German coals of known characteristics (i.e. sulphur content, sulphur forms, etc.) were chosen. Their data were obtained at the high field magnet laboratory at Nijmegen in fields up to 14 Tesla. Both sulphur and ash reductions were shown to scale with $(B / V)$ where $B$ is the magnetic field and $V$ the slurry velocity. This implies that it is possible to process the coal at high velocities and maintain the performance provided sufficiently high magnetic fields are used. The best cleaning results obtained for the coals studied are given in Table 6 all are for $7 \mathrm{~T}$ and $17 \mathrm{~mm} / \mathrm{s}$ slurry velocity except for coal 7(1) which was for a field of 3T. The concentration of the coal in the water was $1: 4 \mathrm{w} / \mathrm{w}$. They concluded that for the coals studied, which had only 1.3 wt\% pyritic sulphur it was possible to get a cleaned product which meets the Dutch $\mathrm{SO}_{2}$ emission limits (equivalent to $1.04 \%$ sulphur).

The average total sulphur content of UK coals as delivered to power station is about $1.6 \mathrm{wt} \%$ with up to $30 \%$ of deliveries having more than $1.9 \mathrm{wt}$. Of this approximately half is organic sulphur. In fact, a survey of UK coals by Wandless 29 has shown that the organic sulphur content is about $0.8 \mathrm{wt}$ for the 


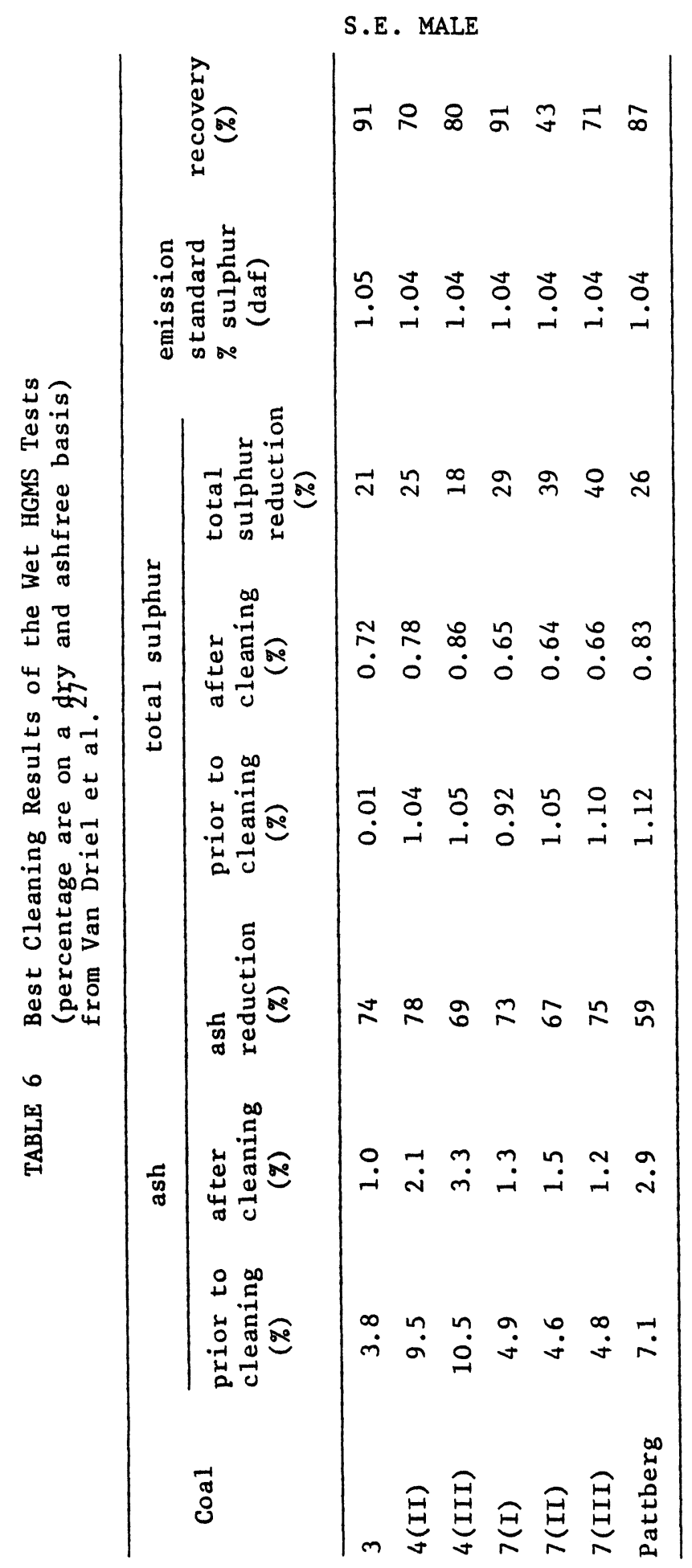


majority of coals. Consequently, nearly all the sulphur in excess of this value is inorganic. As the relative effect of iron pyrite removal on the total sulphur content would increase with increasing initial pyritic content magnetic separation of UK coals has concentrated on coals with total sulphur levels in excess of 2 wt\%. Work 30 on some of these high sulphur coals has shown that provided the inorganic sulphur is sufficiently liberated a significant fraction can be removed, and that the magnetic susceptibility of the inorganic material from different coals is similar. Fig. 4 shows the absolute (yield $\times$ (percent in product)/ (percent in feed)) sulphur and ash reductions for a 25 wt\% Littleton coal-water slurry obtain on a $100 \mathrm{~mm}$ long matrix in a $1.4 \mathrm{~T}$ field. The coal consisted of a $90 \%$ less than 200 mesh $(-74$ $\mu \mathrm{m})$ fraction. Higher coal concentrations were found to reduce the separation efficiency by a significant amount. This is probably due to the hydrodynamic forces dependence on particle interactions.

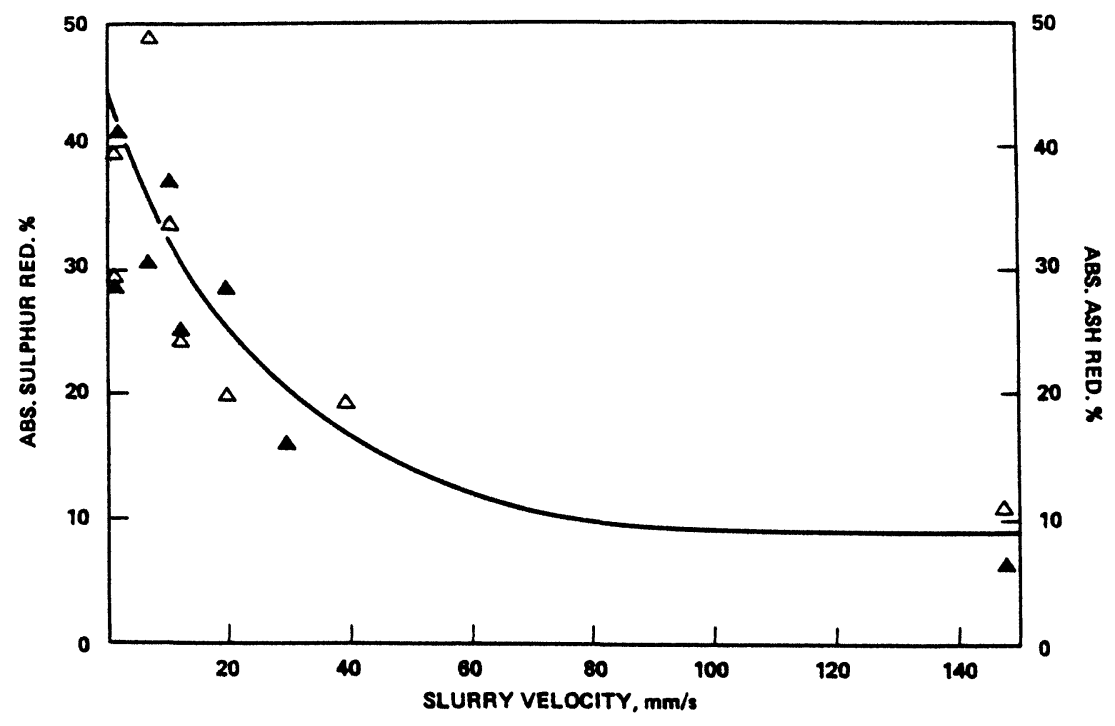

FIGURE 4 The absolute sulphur $(\boldsymbol{\Lambda})$ and ash $(\Delta)$ reduction for a $25 \%(w / w)$ Littleton coal/water slurry. 30 
The results from the water slurry HGMS trials give a broadly similar picture which show that a large fraction of the inorganic pyrite (up to 90 per cent) and a significant amount (up to 50 per cent) of ash can be removed. Even though the results suggest that HGMS desulphurization is technically possible there are major problems that must be overcome before a commercially viable system can be realized. The first is the cost of the preparation of the coal and the subsequent dewatering and handling of the product. This can be as much as 80 to 90 per cent of the total installation. The second is that too much coal is lost in the magnetic processing. Because of the high cost of the ancillary equipment and the loss of coal the wet HGMS does not appear economically feasible at present.

If handling and preparation equipment were part of the total installation and not just associated with the HGMS the economics would be greatly improved. There are a number of schemes in which this would be the case, for example, pipeline slurried coal transportation and the direct combustion of coal-water mixtures in place of fuel oil 31 . Quasi-dry beneficiation

A major barrier to the economic processing of coal/water slurries is the energy required for drying. To overcome this obstacle systems have been proposed that use low boiling point organic liquids ${ }^{32}$ or cryogenic fluid ${ }^{33}$ as the transport medium which can then be recovered and recirculated after the magnetic separation stage. This type of process is common in chemical engineering and it is rather surprising that it has not been applied more of ten to magnetic coal cleaning, especially as the results seem favourable. For example, Maxwell and Kelland ${ }^{32}$ using methanol and methanol/water mixtures as the transport medium showed that for $-0+60$ size fraction of Upper Freeport coal, the reduction of inorganic sulphur was 51 wt. per cent and of ash was 55 wt.percent. 
These results are just as good as those obtained with water only slurries.

Dijkhuis and Kerkdijk ${ }^{33}$ have suggested liquid nitrogen (b.p. $77 \mathrm{~K}$ ) as a transport fluid. Such a system would process the pulverized coal at liquid nitrogen temperatures and then allow a heat leak to boil the cryogenic fluid and thereby obtain quasi-dry processing. An additional benefit is that as the magnetic susceptibility of the mineral matter follows a Curie law, substantially increased susceptibility values would be expected at 1 iquid nitrogen temperatures and so for a given system greater throughputs could be achieved. The feed coal for their experiments was a mixture of Polish and German coals containing 17 per cent ash and 1.07 per cent sulphur and pulverized to 20 per cent minus 200 mesh $(-74 \mu \mathrm{m})$. With the very high transport velocity of $20 \mathrm{~cm} \mathrm{~s}^{-1}$ a reduction of $58 \mathrm{wt}$. per cent for ash and 35 wt. per cent for total sulphur was achieved in a field of $7 \mathrm{~T}$. Slurry velocities of only a few centimetres per second are the usual practice.

Although the results were encouraging Dijkhuis and Kerkdijk point out that cryogenic HGMS would probably be uneconomic unless it was associated with liquid natural gas re-evaporization terminal because of the high cost of heat exchangers. Dry coal beneficiation

Dry HGMS separation is significantly more difficult than wet separation because of the difference between the rheology of gasand liquid-particulate systems. Gas-particulate mixtures suffer from the problem of 'stickiness' which is a direct consequence of the moisture content of the particles. Particles smaller than $10 \mu \mathrm{m}$ are the primary cause ${ }^{34}$ and little can be done except either drying or removal of the fines. The speculation is that the 'stickiness' tends to make the coal and pyrite particles adhere together. This combined with high stokes settling velocity, 
severe pressure drop requirements, poor flow distribution around the matrix and electrostatic interactions severely hinders the separation process.

Studies 24,26 passing unclassified coal through a HGMS have generally shown that the performance is poor. Recently, however, work by Hise and co-workers ${ }^{35-37}$ at Oak Ridge National Laboratory (ORNL) on the separation of carefully dried and classified coals with the fines removed has proved very encouraging with the possibility of pilot plant operation in the near future. In these studies a series of experiments were performed in which coals from Muhlenberg County, Western Kentucky (seam No. 9) and from Lower Freeport were ground to various size fractions between $1 \mathrm{~mm}$ and $10 \mu \mathrm{m}$ and processed by either a HGMS or an isodynamic separator. For all the magnetic separation tests the less than $10 \mu \mathrm{m}$ fines were removed as this was a necessary condition for a satisfactory separation ${ }^{35}$. The overall aim was to measure the degree of liberation of the inorganics, the efficiency of the various separation process, the efficiency as a function of thermal recovery and compare the results with specific gravity

TABLE 7 A selection of dry HGMS results of $2 \mathrm{~T}$ from Hise et al. 35

\begin{tabular}{|c|c|c|c|c|}
\hline \multirow{2}{*}{ Coal } & \multirow{2}{*}{$\begin{array}{l}\text { Flow } \\
\text { Rate } \\
\text { ft/min }\end{array}$} & \multicolumn{2}{|c|}{ Percentage Reduction } & \multirow{2}{*}{$\begin{array}{l}\text { Thermal } \\
\text { Recovery }\end{array}$} \\
\hline & & Sulphur & $\overline{\mathrm{Ash}}$ & \\
\hline $\begin{array}{l}\text { Lower Freeport } \\
\qquad(-100 /+200)\end{array}$ & $\begin{array}{l}50 \\
92\end{array}$ & $\begin{array}{l}63.3 \\
61.7\end{array}$ & $\begin{array}{l}56.3 \\
62.0\end{array}$ & $\begin{array}{l}94.7 \\
95.6\end{array}$ \\
\hline \multirow{2}{*}{$\begin{array}{c}\text { Kentucky (No. 9) } \\
(-100 /+200)\end{array}$} & 50 & 23.0 & 45.6 & 89.2 \\
\hline & 92 & 23 & 51.9 & 92.4 \\
\hline \multirow[t]{2}{*}{$(-25 /+100)$} & 50 & 19.9 & 49.1 & 93.0 \\
\hline & 92 & 18.4 & 40.8 & 93.9 \\
\hline
\end{tabular}




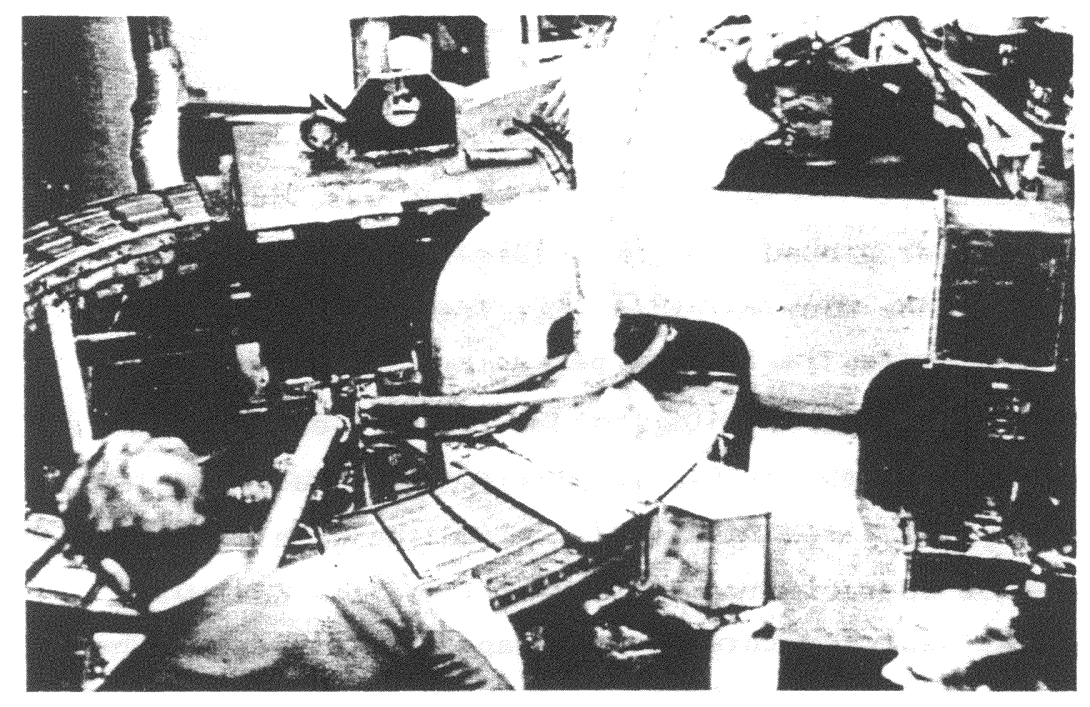

FIGURE 5 A small continuous HGMS carousel (Sala Inc.). 
separations on the same coals. The measurements using the HGMS and isodynamic separator showed that for liberated minerals in dry crushed coal both separators reduced sulphur and ash with comparable efficiency to that of the specific gravity process for a size fraction $-24+100$ mesh $(707-149 \mu \mathrm{m})$. The significance of the work was not that it demonstrated that dry magnetic desulphurization of coal can be achieved, as this had been done before ${ }^{11,23}$, but the detail with which the grinding, grade recovery and test conditions were reported. In fact Hise states that his purpose was to '... identify successful operating conditions'.

The HGMS results ${ }^{36}$ were obtained on a commercial high gradient separator with run-of-mine coals which were deshaled, jawcrushed and roller ground, and then classified to the required size fraction. Of the many matrix designs tested expanded metal discs were found to give the highest percentage removal of magnetic material whilst retaining the least amount of coal. A selection of the HGMS results for air transported coal using the same matrix array are given in Table 7 . From the data the most successful mode of operation was to gravity feed the coal with very low transport velocity through an expanded metal mesh. The best results were obtained for Lower Freeport coal of size fraction 150 to $44 \mu \mathrm{m}$ and Western Kentucky No. 9 coal of size fraction 700 to $74 \mu \mathrm{m}$. These operating conditions are well suited to continuous HGMS using a carousel type machine (Fig. 5 and 6 ). The results of trials using just such a machine have been reported by Hise et al. ${ }^{37}$ and demonstrated that both sulphur and ash could be reduced by amounts similar to that obtained using a batch HGMS for processing rates up to 1 ton per hr. For successful operation the surface moisture content had to be below 4 per cent. A summary of the results from the ORNL studies are given in Fig. 7 and 8 for specific gravity, batch and continuous HGM separations. 


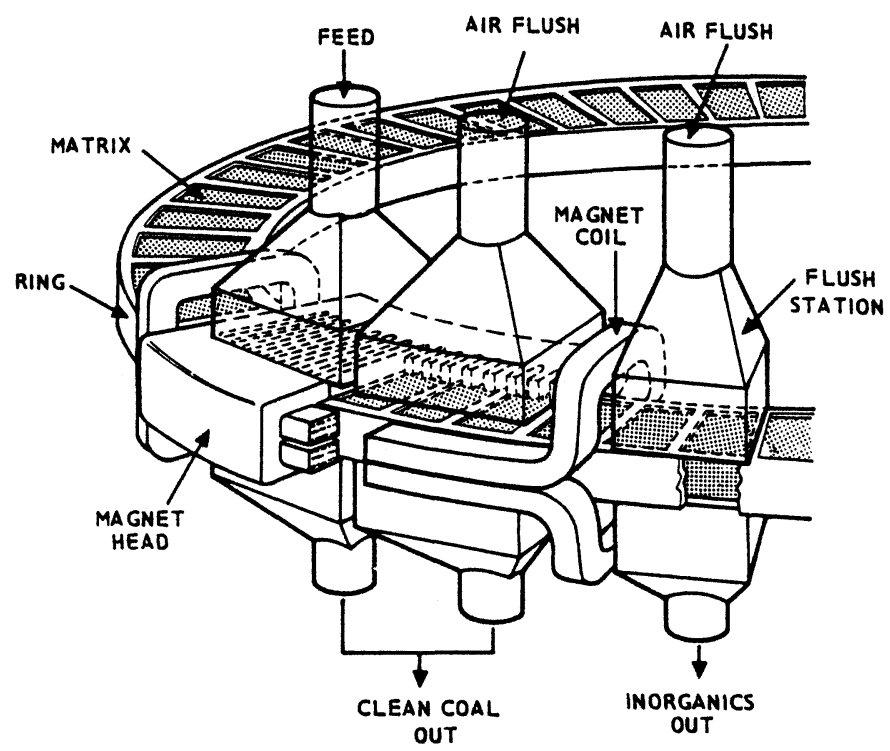

FIGURE 6 A schematic of a carousel HGMS (Sala Ine.)

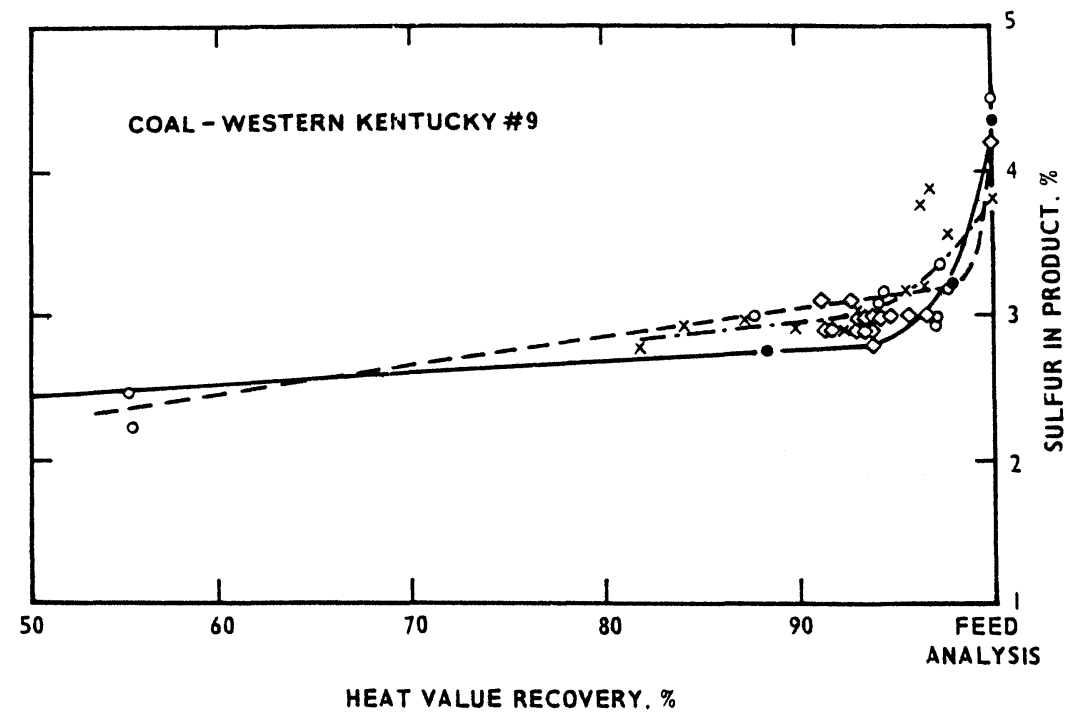

FIGURE 7 Sulphur removal by carousel $(\theta)$ batch solenoid $(X)$ and gravity $(0, \bullet) 35-37$ 


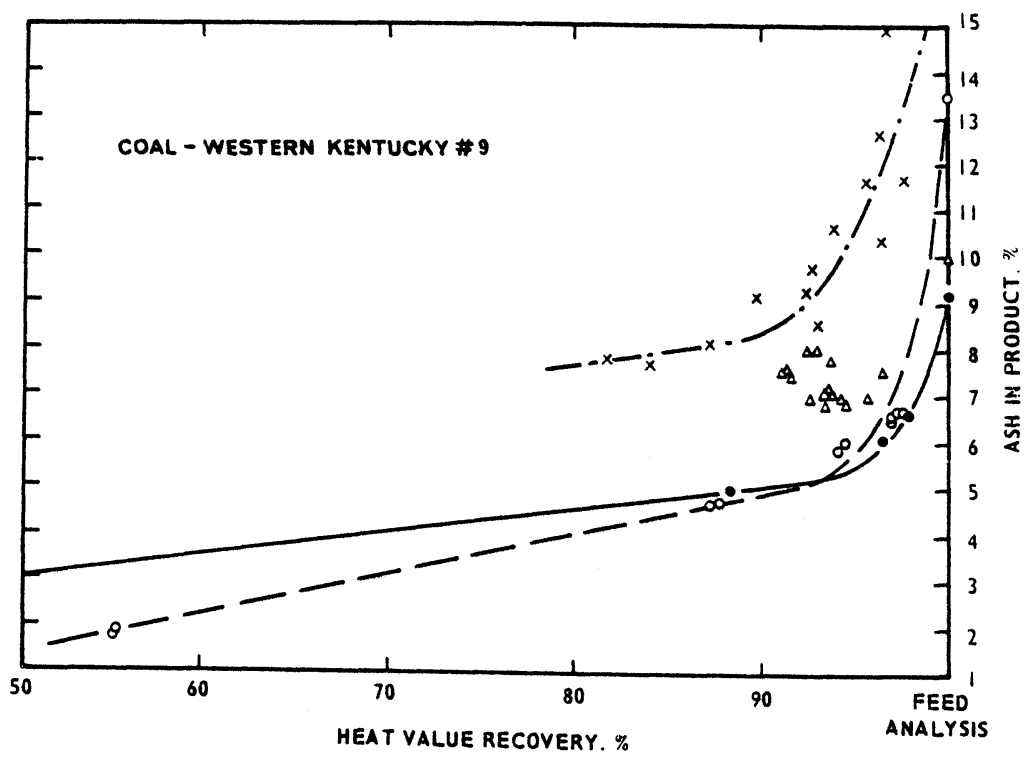

FIGURE 8 Comparison of ash removal by HGMS carousel,

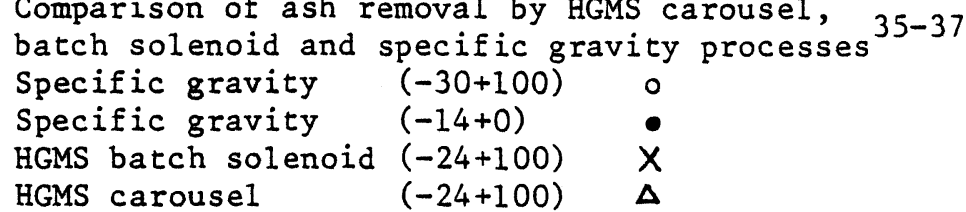

The transportation of coal through an HGMS is a major problem in dry separation especially for unclassified coal or coal with fines. Liu and co-workers ${ }^{38}$ have attempted to solve this problem by developing a fluidized bed magnetic separator. The separator consists of a superconducting solenoid with an active length of about $1 \mathrm{~m}$, within which an expanded metal matrix is located. The coal is fed to the separator via a tube of sufficiently small diameter than even the largest particles are fluidized and transported. The diameter of the matrix tube was such that the majority of particles were kept in suspension without any carry forward. The fines $(2$ to $10 \mu \mathrm{m}$ ) are elutriated out of the system. The coal is fed into the matrix with the field on, after a residence time of about 5 minutes the air flow is stopped and the desulphurized coal falls from the matrix volume. Removing the 
magnetic field releases the magnetic material from the separator.

This magnetic separator works with size fraction of -200 mesh $(75 \mu \mathrm{m})$ which is probably consistent with the ORNL work as the fluidized bed separator acts as a classifier-separator combination with elutriation of the fines. Whether the fines should be kept or discarded seems to depend on the grind and type of coal (i.e. quantity of fusinite present, morphology of the iron pyrites, etc.).

The efficiency of fluidized bed separator is comparable with that of the gravity fed HGMS - approximately a 25 per cent reduction in total sulphur. There are, however, some disadvantages; the long residence times (25 mins) necessary to affect a reasonable separation means that the throughput is small and even to achieve this residence time the magnetic field must be high. The present design operates only in a batch mode unlike the carousel. The obvious advantages of this separator is its potential for handling -200 mesh size fraction but even so it is still far from a practical application compared to the known technology of the HGMS carousel.

To clean as-delivered power station coal by dry magnetic separation is clearly possible provided the coal has been correctly classified. Unfortunately the classification stage may produce a considerable loss of coal and thereby render the whole process uneconomic. To overcome this it is possible to take advantage of classification stages on existing power station plant. Certain types of roller mill incorporate a classifier to recycle material which is insufficiently ground. This material is not only fairly large $(>50 \mu \mathrm{m})$ but is enriched with inorganics because they are more difficult to grind and have a higher density.

Dörr et al. ${ }^{39}$ have utilized such a scheme using a superconducting HGMS. The superconducting magnet had a room temperature bore of $108 \mathrm{~mm}$, an overall length of $350 \mathrm{~mm}$ and a maximum field of $6 \mathrm{~T}$. The separtor operated on the recycle loop of a roller mill classifier at throughputs up to $100 \mathrm{~kg} \mathrm{hr}^{-1}$ and 
at a field of $3.6 \mathrm{~T}$. A number of matrix designs were tested and the two which proved most effective consisted of a wire mesh of various diameters and a roller with radial wires attached. Two types of coal from Walsum and Westerholt collieries were tested and gave total sulphur reductions between 20 and 39 wt. per cent with coal losses between 3 and 13 wt. per cent. The correlation between the separation efficiency of the total sulphur and combustible matter losses are shown in Fig. 9.

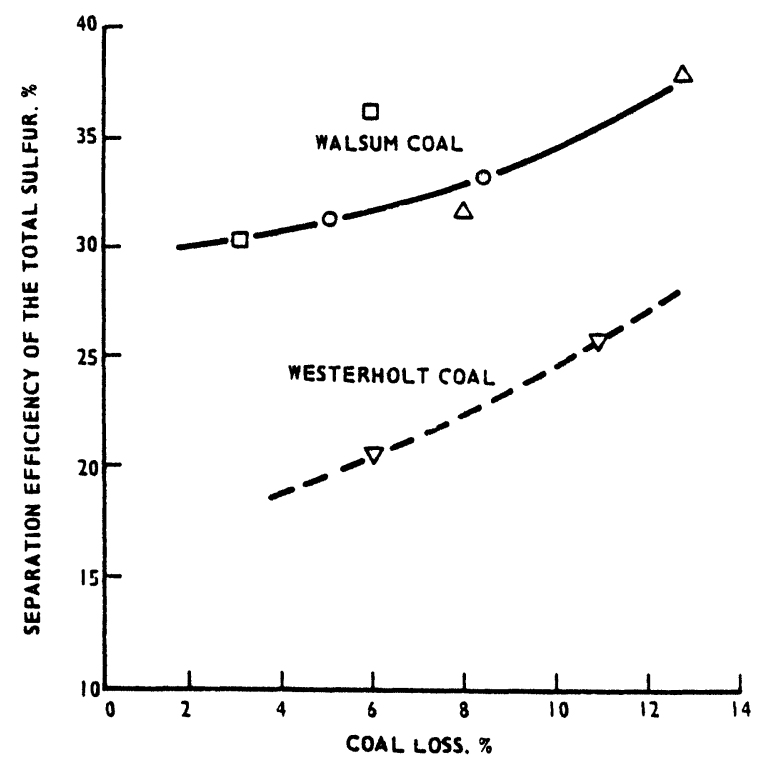

FIGURE 9 The separation efficiency for the total sulphur and combustible matter losses for a roller mill-HGMS combination, magnetic field $3.6 \mathrm{~T}^{39}$ Spiked roller matrix ( $1.5 \mathrm{~mm}$ diameter) $\square$ Wire mesh matrix (1.8 mm diameter) 0 Wire mesh matrix (2.2 mm diameter) $\nabla, \Delta$.

Although the work proved technically successful the economics of the magnetic separation process were more difficult to judge as it could only assist flue gas desulphurization in the case of coal with over 0.6 per cent organic sulphur if the Federal Republic of Germany introduced the proposed emission limits of $3.75 \mathrm{~kg} \mathrm{sO} / 2 / \mathrm{MWh}$. 
Thus a combination of pulverized coal and flue gas desulphurization had to be considered and Dörr concluded that this may be economically advantageous but that further development work was still required.

\section{OPEN GRADIENT MAGNETIC SEPARATION}

The production of very high magnetic field gradients by conventional HGMS requires the use of secondary pole pieces in an initially high magnetic field. Typically, the secondary pole pieces are stainless steel fibres. Unfortunately there are a number of problems with HGMS using this design. The risk of blockage is always present especially if the supply of magnetic material exceeds the available deposition sites. The rate of throughput is limited by the residence time necessary to achieve a satisfactory separation. The rapid rate of decrease in the field gradient with distance from the fibre means that some magnetic particles pass at too great a distance to be trapped. An open gradient magnetic separator $21,40-42$ (OGMS) may overcome these problems.

The best known type of OGMS is the isodynamic separator which gives good separation of weakly magnetic material but is essentially a laboratory instrument with a very small throughput. This is due to the construction whereby the gradients are produced by specially shaped pole pieces of an electromagnet. The gap between the pole pieces has to be just a few millimetres in order to produce the necessary fields and gradients. Both technically and economically it is not feasible to scale the isodynamic separator to commercial size using conventional electromagnets. To achieve open gradient separation on a large scale superconducting magnets must be used.

The first published work using an open gradient superconducting separator was by Cohen and Good 40,41 . The separator consisted of a superconducting quadrupole magnet with an 
annular flow duct located around the outside of the magnet. Continuous separation is achieved by using the vortex flow in the duct to carry out all the particles into the narrow region of high magnetic force located near the inner wall of the duct. The magnetic particles are trapped at the wall and move forward under the influence of the fluid drag of the primary flow until they are discharged from the duct. The magnetic field produced in the separator was $1.4 \mathrm{~T}$.

Cohen and Good perform a number of trials with coal slurries made from Pennsylvanian coal. Two different coals were used, coal 1 contained 4.5 wt. per cent inorganic sulphur and coal 2 contained 9.0 wt. per cent inorganic sulphur and 76 wt. per cent ash. They failed to adequately desulphurize coal 1 but satisfactorily separated coal 2;83 wt. per cent of the inorganic sulphur was removed. They suggested that the failure to separate coal 1 was due to the inadequate liberation of pyrites. However, the coal was ground to $150 \mu \mathrm{m}$ which is typical of other separation experiments on similar coals which have proved successful. Importantly, coal 1 was a commercial coal whereas a coal 2 with 76 wt. per cent of inorganic matter was not. It seems probable that the sulphur particles in coal 2 had a high paramagnetic impurity content, thereby raising their magnetic susceptibility to a value which allowed them to be separated by the Cohen-Good separator. Their results may indicate that the separator had insufficient field gradient to desulphurize typical commercial coals with low susceptibility pyritic particles. More recently Hise ${ }^{21,37}$ has published work on an open gradient superconducting system consisting of two coils connected such that a cusp mode solenoid is formed (Fig. 10). The solenoid is $30 \mathrm{~cm}$ long and is suspended in a cryostat with a $9 \mathrm{~cm}$ room temperature bore. It was designed to have a field times field gradient product of the same order as the isodynamic separator. The field gradient in the bore of the solenoid is in the radial 
direction increasing towards the walls. Diamagnetic particles are pushed to the centre and therefore the separation is essentially diamagnetic. Using a circular ring feed with flow rates up to $300 \mathrm{~kg} \mathrm{hr}^{-1}$ the results from the cusp mode superconducting OGMS compare well with the specific gravity separations. The results from a Western Kentucky coal seam No. 9 with a size fraction of $-600 /+150 \mu \mathrm{m}$ are shown in Fig. 11 .

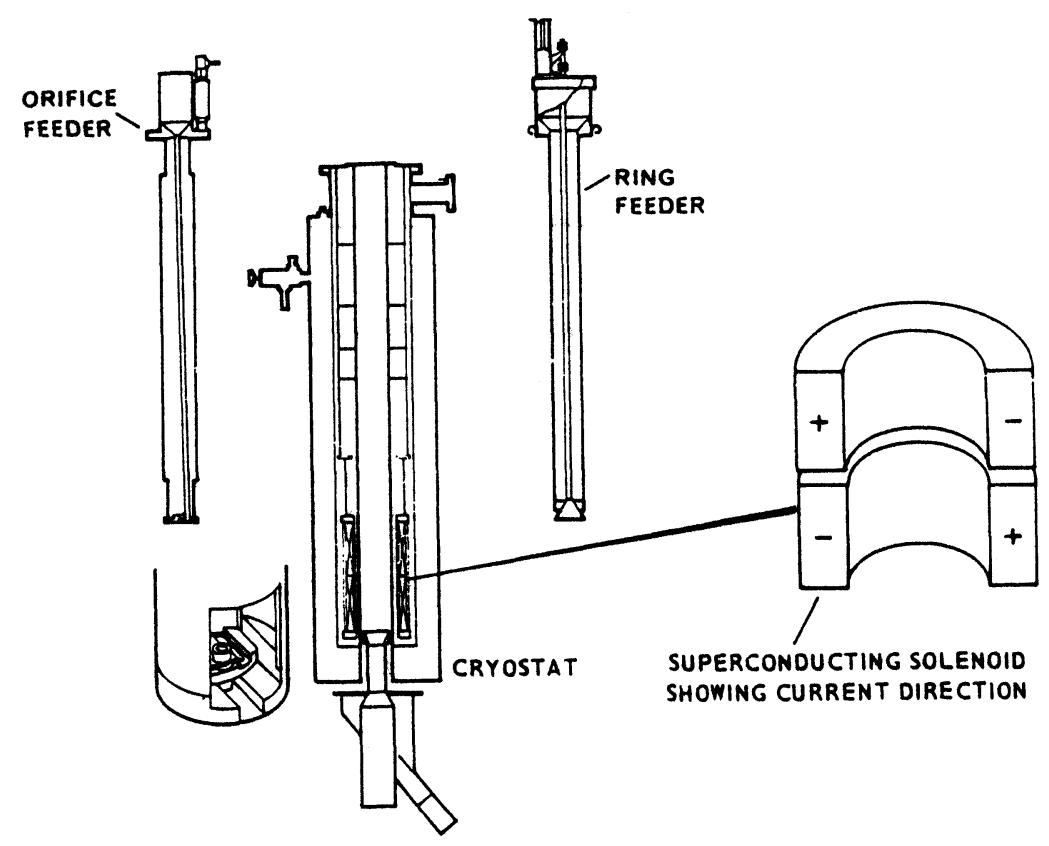

FIGURE 10 A cusp-mode superconducting open gradient magnetic separator 21 .

\section{MAGNETIC ENHANCEMENT}

If the magnetic susceptibility of iron pyrite could be increased then the performance of the magnetic separation process would be 


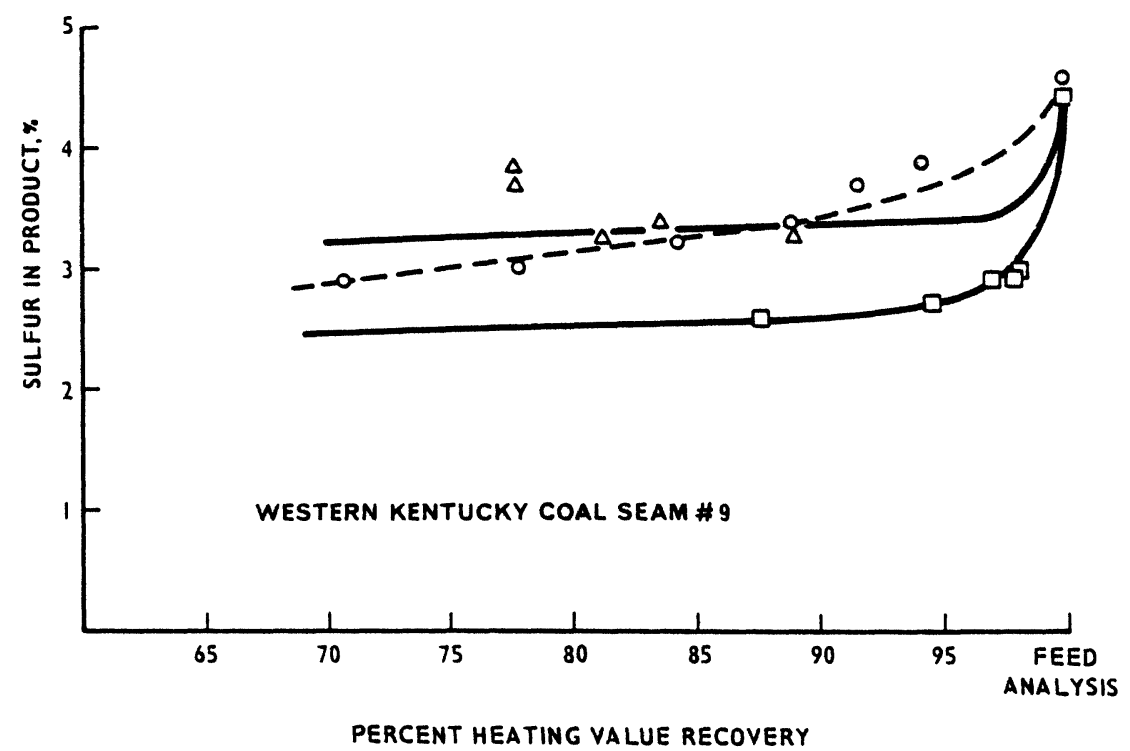

FIGURE 11 A comparison of open gradient magnetic separation by Franz isodynamic separator $(--0--)$ and superconducting magnet $(-\Delta-)$ with the gravimetric method 21,42 ( $\square)$.

greatly improved. Specifically, increased throughput and use of conventional medium gradient separators may then be possible. Although there were numerous early attempts to enhance the magnetization of pyrite by steam treatment, the results were inconclusive. This is hardky surprising as there are many possible chemical reactions in a steam atmosphere and numerous iron-sulphur end products.

To increase the magnetic susceptibility of $\mathrm{FeS}_{2}$ there are various thermochemical paths which could be adopted but perhaps the simplest is to heat the iron pyrite in a vacuum. The combination of decomposition and phase transformation which then 
occurs can be represented as follows:

$$
\begin{aligned}
& \mathrm{FeS}_{2} \stackrel{\text { Hẹt }}{\mathrm{FeS}_{2-\mathrm{x}}}+\mathrm{xS}_{\text {sub }} \\
& \mathrm{FeS}_{2-\mathrm{x}} \rightarrow \mathrm{D}_{\delta} \mathrm{Fe}_{1-\delta} \mathrm{S} \\
& \mathrm{Fe}_{1-\delta} \mathrm{S}\left(+\mathrm{FeS}_{2}\right) \rightarrow \mathrm{Fe}_{1-\delta}, \mathrm{S}
\end{aligned}
$$

The application of heat to iron pyrite sublimes some of the sulphur leaving an iron rich compound which will eventually change into the appropriate thermodynamic structure for that composition and temperature. Spontaneous transformation to the equilibrium state will not happen as the process by which the transition occurs is mass transport (vacancy rearrangement). Therefore considerable time delays may be involved before the thermodynamically stable non-stoichiometric iron sulphur phase is reached. Additional heating may produce a mixture of compounds by solid state reactions and further decomposition. The aim is to produce the ferrimagnetic monoclinic pyrrhotite and hence substantially increase the magnetic susceptibility of the pyrite particles.

If, in addition, chemical species are included (by heating in an $\mathrm{H}_{2} \mathrm{O}, \mathrm{H}_{2}$, CO, etc. atmosphere) the process becomes complicated and careful experimental control is needed to give reproducible results. Nevertheless, several studies ${ }^{43,44}$ have shown that under the appropriate conditions the conversion of iron pyrite to monoclinic pyrrhotite is possible. The problem is that temperature in excess of $300^{\circ} \mathrm{C}$ are needed. For iron pyrite in coal considerable energy would be wasted in heating the coal and also decomposition of the coal may occur.

To overcome these problems Ergun and Bean ${ }^{18}$, suggested and demonstrated the selective heating of pyrite by microwaves. This has the advantage that the pyrite can be heated to temperatures well above $400^{\circ} \mathrm{C}$, thus converting a significant fraction to the 
ferrimagnetic phase, while the coal is kept well below this temperature.

The amount of electromagnetic energy a material absorbs depends on the imaginary part of the dielectric constant. If, at a given frequency, the imaginary dielectric constant of a material is small, the material is transparent at that frequency and absorbs little energy. To selectively heat pyrite there must be a considerable difference between its dielectric constant and that of coal. Ergun and Bean measured the dielectric constants of coal and pyrite for frequencies up to $100 \mathrm{MHz}$ and found that the pyrite dielectric constant was one hundred times greater than that of coal for frequencies above $10 \mathrm{MHz}$. They heated pure pyrite and 5 wt. per cent pyrite-coal mixtures at $30 \mathrm{MHz}, 2.45 \mathrm{GHz}$ and $10 \mathrm{GHz}$. At the lowest frequency only very coarse pyrite ( $1 \mathrm{~mm}$ diameter) was heated sufficiently to become magnetic; using the $2.45 \mathrm{GHz}$ radiation the pyrite samples became hot enough to burn the plastic sample holders and were definitely magnetic but coal-pyrite mixtures gave inconclusive results. The $10.0 \mathrm{GHz}$ results were even more encouraging, in that the pyrite regardless of size was heated to a temperature in excess of $300^{\circ} \mathrm{C}$ in a few seconds whereas the coal only rose to $150^{\circ} \mathrm{C}$ after 30 minutes; the samples became very magnetic.

Recent work by Fanslow et al. ${ }^{45}$ has shown that the pyrite and mineral matter in coal are heated 2 to 3 times faster than the carbonaceous coal at a microwave frequency of $2.45 \mathrm{GHz}$. Selective microwave heating, however, has yet to show that it can significantly increase the magnetic susceptibility of iron pyrite particles in coal and thereby increase their magnetic separation efficiency.

Hazen Research Inc. ${ }^{46}$ have invented a process which selectively enhances the pyrite susceptibility by chemical means. It is known as the 'Magnex' process and involves heating the pulverized coal to $170^{\circ} \mathrm{C}$ and then subjecting it to iron 
pentacarbonyl vapour. The iron is selectively deposited on the mineral matter which can then be processed using low or medium gradient magnetic separators. Reductions of up to $85 \mathrm{wt}$. per cent of the pyritic sulphur and 26 wt. per cent of the ash have been reported $^{26}$ for a Pennsylvania coal using an induced-magnetic roll separator. Although the process has the advantage of working at low temperature and pressure the toxicity and process consumption (32 1b/ton of coal) of iron pentacarbonyl are distinct problems. At present the process is still under development.

\section{MAGNETIC SEPARATION OF LIQUIFIED COAL}

A number of countries are investigating the production of liquified fuels from coals. In the solvent refining process the coal is liquified by dissolution of the carbonaceous part by a solvent at high temperature and pressure. The mineral matter in the coal does not dissolve and must be separated from coal solution to produce a clean product. Precoat filters have been used but cost projections indicate that they may be very expensive ${ }^{47}$. Fortuitously in the liquefaction process the iron pyrite is converted to a pyrrhotite type phase and consequently magnetic filtration is likely to be effective. Moreover, the liquefaction process liberates more effectively the mineral matter from the organic material than crushing the coal. A typical particle size of the SRC filter feed is approximately 5 to $19 \mu \mathrm{m}^{25}$.

Work by Hydrocarbon Research Inc. (HRI) ${ }^{48}$ using commercial HGMS with steel wool matrix typically removed up to 90 per cent of the inorganic sulphur and up to 30 per cent of the ash from solvent refined coal filter feed derived from Catalytic Inc. plant at Wilsonville, Ala. As with all liquefaction processes the filtration must be conducted at high temperature and consequently the HRI study was performed at $176^{\circ} \mathrm{C}$. Lin et a1. ${ }^{25}$ again using 
Wilsonville SRC filter feed obtained similar results for both ash and inorganic sulphur removal.

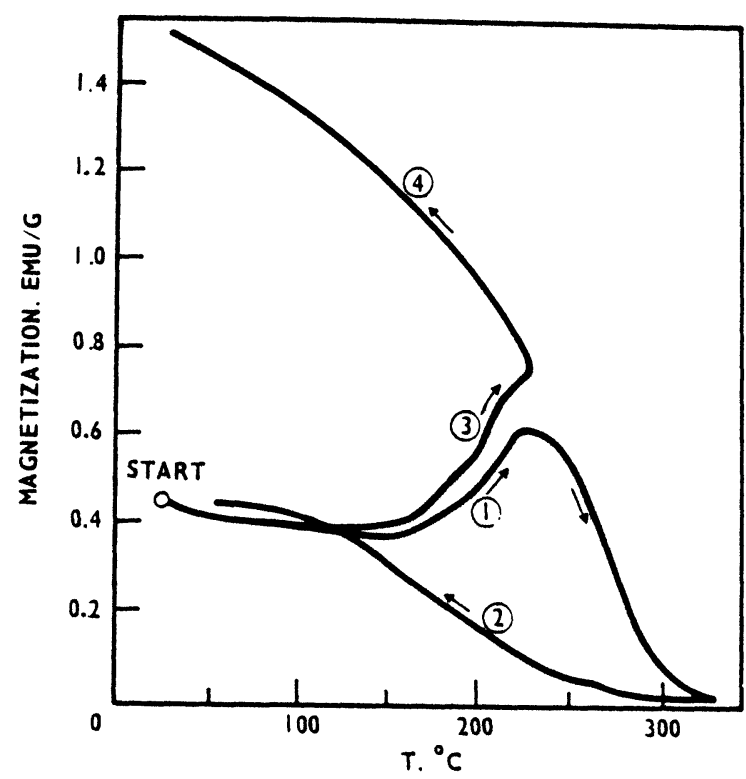

FIGURE 12 The temperature dependence of the magnetization of SRC filter cake solids ${ }^{48}$.

Using steel wool in the bore of a Bitter solenoid Maxwell and Kelland ${ }^{32}$ managed, under favourable temperature and magnetic field conditions, to remove substantially all the inorganic sulphur and up to $40 \mathrm{wt}$. per cent of the ash. These results were achieved at a temperature in the region of $221^{\circ} \mathrm{C}$ and with a $2.0 \mathrm{~T}$ field. Separation tests with fields up to $8 \mathrm{~T}$ were also performed. The feedstock was a SRC filter-feed from Wilsonville, Alabama, plant derived from Monteray coal.

One other most interesting aspect of this work was the study of the temperature dependence of the separation process. The thermomagnetic properties of SRC filter cake taken from the work of Jacobs and Levinson ${ }^{48}$ are shown in Fig. 12. The temperature 
path followed is indicated by the arrow. The changes in the magnetization are believed to be caused by transition from hexagonal to monoclinic pyrrholite which occur in the region of $220^{\circ} \mathrm{C}$. As the temperature is increased further a mixed phase is formed with lower magnetization. On cooling the kinetics are such that the monoclinic phase does not reform even below $220^{\circ} \mathrm{C}$. The results of Maxwell for the temperature dependence of the separation are given in Fig. 13. The ordinate is the ratio of insoluble sulphur in the filtrate to that in the feed. The results of the two studies correlate particularly well and are of considerable practical importance in ensuring that the filtration process is performed under optimum conditions.

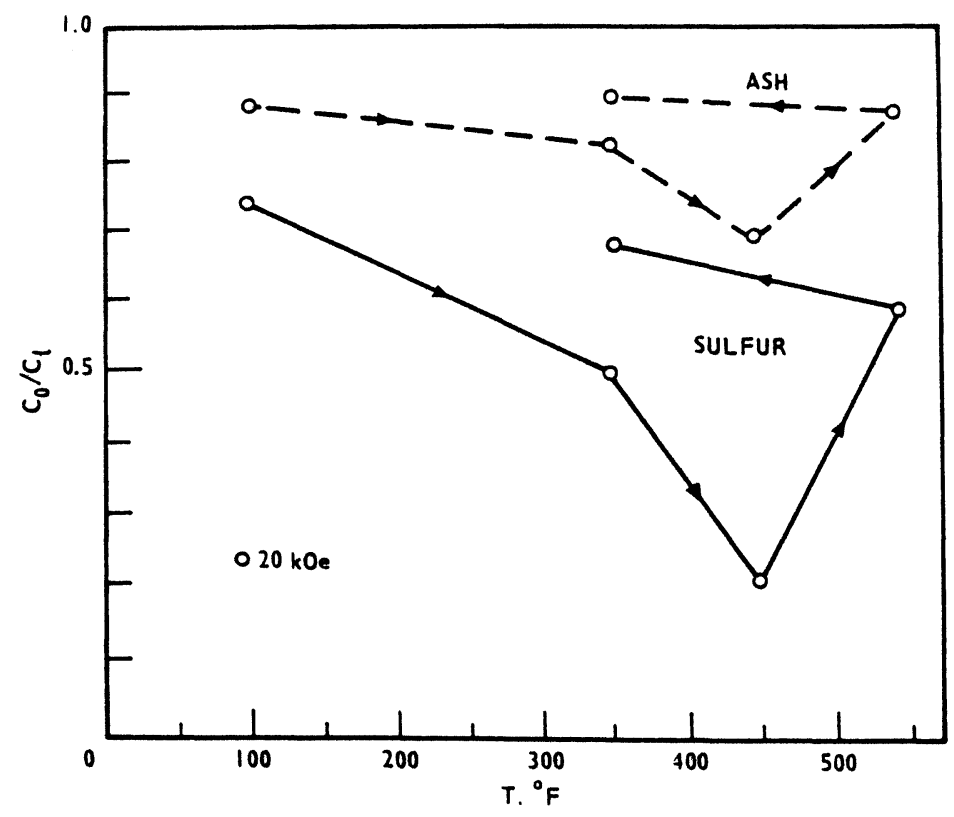

FIGURE 13 The temperature dependence of the concentration ratio for ash and tetrahydrofurane insoluble sulphur 49 . 


\section{SUMMARY}

The following qualitative conclusion regarding magnetic beneficiation of coal can be drawn:

- High gradient magnetic separation can reduce pyritic sulphur by 80 wt. per cent or more from pulverized coal slurries and, with appropriate classification, from dry coal streams. Ash forming mineral matter is also removed but less efficiently (20-50 wt per cent reduction).

- Clean coal recovery of 75 per cent or more is possible.

- The reductions depend very much on the particular coal and on the size to which it is ground. This also applies to many other coal cleaning processes.

- Process rates sufficient for production plants are possible although more than one magnetic separator may be required.

Magnetic separation of coal is a clear example of the trade off between grade and recovery, for a given coal grind increasing the magnetic force reduces the amount of clean coal recovered but increases its quality. The exact balance between recovery and grade depends critically on the particular application. For example, if a magnetic separator were to be used to clean waste fines from a heavy media plant the product recovery could be sacrificed for grade. However, the reverse would be true if the separator were to be used as an add-on facility to a steam plant to reduce emission of $\mathrm{SO}_{2}$. A large percentage loss of coal may make the process uneconomic compared to other $\mathrm{SO}_{2}$ reduction methods. One of the major reasons for the grade/recovery problem is the incomplete liberation of the mineral matter from the coal and the possible agglomeration of particles after grinding. This, combined with the difficulties in reducing the organic sulphur, means that inorganic sulphur reductions of 80 per cent or more are particularly good. 
The variable nature of the mineral matter in coal both in size distribution, morphology and chemical composition, inevitably means that each coal has to be treated as a special case. Certain coals may therefore be particularly suitable for magnetic processing and so magnetic separation should be viewed not as an all-embracing coal cleaning technology but as part of a coal preparation plant for processing certain coals or coal fractions.

\section{APPENDIX 1: CONVERSION BETWEEN SULPHUR IN COAL AND EMISSION LEVELS}

Depending upon the context different units are used to express the $\mathrm{SO}_{2}$ emission levels. The following is an approximate conversion between the most common.

$$
\begin{aligned}
& 2.0 \% \mathrm{~S} \text { in fuel } \\
& \cong 2.8 \mathrm{~b} \mathrm{SO}_{2} / 10^{6} \mathrm{~B} . \mathrm{T} . \mathrm{U} . \\
& \cong 12.5 \mathrm{~kg} \mathrm{SO}{ }_{2} / \mathrm{MWh} \\
& \cong 1500 \mathrm{ppm} \mathrm{SO} \\
& \cong 4000 \mathrm{mg} / \mathrm{m}^{3} \\
& \cong 1200 \mathrm{~g} \mathrm{SO}_{2} / \mathrm{GJ}
\end{aligned}
$$

\section{APPENDIX 2: NOMENCLATURE FOR IRON PYRRHOTITE SYSTEM}

The nomenclature used is based on the NiAs superstructure, which has $a=3.44 \AA, c=5.78 \AA$ and $c / a \cong 1.68$. For a perfect hexagonal close-packed lattice $c / a=1.633$. The various pyrrhotites are designated as $\mathrm{nC}$ where $\mathrm{n}$ is an integral or non-integral value of the cell edge of the hexagonal NiAs structure appropriate to the Fe-S under consideration. For example, trolite has $a=\sqrt{ } 3 \mathrm{~A}$ and $\mathrm{c}=2 \mathrm{C}$ where $\mathrm{A}$ and $\mathrm{C}$ are the cell dimensions for NiAs. Hence this compound is referred to as $2 \mathrm{C}$ pyrrhotite. Only the c-axis dimension is usually quoted. A complete list is given in Table 8. 
TABLE 8 The Nomenclature for the Iron Pyrrhotite System

\begin{tabular}{|c|c|c|c|c|}
\hline $\begin{array}{l}\text { Chemical } \\
\text { Formula }\end{array}$ & $\mathrm{Fe}_{1-\delta} \mathrm{S}$ & $\delta$ & $\mathrm{nC}$ & Name \\
\hline $\mathrm{Fe} \mathrm{S}$ & Fe $S$ & 0 & $2 \mathrm{C}$ & Trolite \\
\hline $\mathrm{Fe}_{11} \mathrm{~S}_{12}$ & $\mathrm{Fe}_{0.92} \mathrm{~S}$ & 0.08 & $6 C$ & \\
\hline $\mathrm{Fe}_{10} \mathrm{~S}_{11}$ & $\mathrm{Fe}_{0.91} \mathrm{~S}$ & 0.09 & $11 C$ & Hexagonal pyrrhotite \\
\hline $\mathrm{Fe}_{9} \quad \mathrm{~S}_{10}$ & $\mathrm{Fe}_{0.91} \mathrm{~S}$ & 0.10 & $5 C$ & \\
\hline $\mathrm{Fe}_{7} \quad \mathrm{~S}_{8}$ & $\mathrm{Fe}_{0.875} \mathrm{~S}$ & 0.125 & $4 \mathrm{C}$ & Monoclinic pyrrhotite \\
\hline
\end{tabular}

\section{ACKNOWLEDGEMENTS}

I would like to thank $\operatorname{Dr} A$. Dillon for permission to use photographs 2. This work was carried out at the Central Electricity Research Laboratories and is published by permission of the Central Electricity Generating Board. 


\section{REFERENCES}

1. EEC Preliminary Draft Directive, XI/792/82-EN, 1982

2. Nunenkamp, D.C., Coal Cleaning: An Introduction and Overview, in Coal Desulphurization Prior to Combustion, Eliot, R.C., Ed., Noyes Data Corporation, New Jersey, 1978, Cap. 1

3. Stach, E., Stach's Textbook of Coal Petrology, Gebrüder Bromtraeger, Berlin, 1975

4. Berner, R.A., Sedimentary Pyrite Formation, Am. J. Sci., 268, 1,1970

5. Sweeney, R.E. and Kaplan, I.R., Pyrite Framboid Formation; laboratory synthesis and marine sediments, Econ. Geol., 68 1973

6. Ward, J.C., Structure and Properties of Some Iron Sulphides, Rev. Pure and Appl. Chem., 20, 175, 1970

7. Goodenough, J.B., Structural Chemistry of Iron Sulfides, Mat. Res. Bul1., 13, 1305, 1978

8. Burgardt, P. and Seehra, M.S., Magnetic Susceptibility of Iron Pyrite $\left(\mathrm{FeS}_{2}\right)$ between 4.2 and $620 \mathrm{k}$, Sol. State Comm., $22,153,1977$

9. Power, L.F. and Fine, H.A., The Iron-Sulphur System, Minerals Sci. Engng., 8, 106, 1976

10. Male, S.E., Magnetic Measurements on Coal, J. Phys. D: App1. Phys. 13, 167, 1980

11. Kester, W.M., The effect of high-intensity magnetic cleaning on pulverised high-sulphur bituminous coals, Master Thesis, School of Mines, West Virginia University, West Virginia, 1966

12. Kester, W.M., Leonard, J.W. and Wilson, E.W., Reduction of Sulfur from Steam Coals by Magnetic Methods, Min. Congr. J., $53,70,1967$

13. Wooster, W.A. and Wooster, N., The Magnetic Properties of Coal, Proceedings of a conference on the ultra-fine structure of coal and coke, British Coal Utilization Research Association, 1944

14. Yurovskii, A.Z. and Remesnikow, J.D., Thermomagnetic Methods of Concentrating and Desulphurizing Coal, Koks. I. Khim., $12,8,1958$

15. Siddiqui, S., Process for desulphurization and concentration of coal, German Patent, 1,005,012, 1957

16. Husain, S., Ruizui, S.H. and Ouarshi, M.M., Structural Studies on the Magnetic Fraction of Steam-Treated Makerwal Coal, Pakistan J. Sci. Ind. Res., 3, 40, 1960

17. Kester, W.M., Magnetic Demineralization of Pulverized coal, Min. Eng., 17, 72, 1965

18. Ergun, S. and Bean, E.H., Magnetic separation of pyrite from coals, U.S. Dept. of Interior, Bureau of Mines, Rept. No. 7181, 1968 
19. Kol m, H., Maxwell, E., Oberteuffer, J., Kelland, D., delatour, C. and Marston, P., High Intensity Magnetic Filtration, Magnetism and Magnetic Materials Conf. Proceedings, Am. Inst. Physics, 5, 949, 1971 (abstr)

20. Marston, P.G. and Nolan, J.J., Magnetic Separator, U.S. Patent 3, 627,678, 1971

21. Hise, E.C., Holman, A.S, and Fridlaender, F.J., Development High-Gradient and Open-Gradient Magnetic Separation of Dry Fine Coal, IEEE Trans. on Magn., MAG-17, 3314, 1981

22. Trindade, S.C., Studies on the magnetic demineralization of Coal, Ph.D. Thesis, Dept. of Chem. Eng., Massachusetts

Institute of Technology, Cambridge, Mass., 1973

23. Trindade, S.C., Howard, B.J., Kolm, H.H. and Powers, C.J., Magnetic Desulphurization of Coal, Fuel, 53, 178, 1974

24. Murray, H.H., Beneficiation of Selected Industrial Minerals and Coal by HGMS, IEEE Trans. Magn., MAG-12, 498, 1976

25. Lin, C.H., Liu, Y.A., Vives, D.L., Oak, M.J., Crow, G.E. and Huffman, E.L., Pilot Scale Studies of Sulfur and Ash Removal from Coals by HGMS, IEEE Trans. Magn., MAG-12, 513, 1976

26. Coal Preparation Using Magnetic Separation, Electric Power Res. Inst., Palo Alto, CA. Report EPRI CS-1517, Vols. 1-5, 1980

27. van Driel, C.P., Kerkdijk, C.B.W., Segal, H.R. and Sikkenga, J., Coal Cleaning by HGMS, FDO Technische Adviseurs B.C., Amsterdam, 1983

28. Kerkdijk, C.B.W., van Driel, C.P. and Troost, G.K., Mineral Matter Composition and Particle Size Effects in HGMS Coal Cleaning, Int. Symposium on Electrical and Magnetic Separation Tech., Antwerp, 1984

29. Wandless, A.M., J. Inst. of Fuel, 32, 258-66, 1959

30. Male, S.E., Magnetic Susceptibility and Separation of Inorganic Material from U.K. Coals. J. Phys. D: Appl. Phys. $17,155,1984$

31. Coal-Water Slurry as Utility Boiler Fuel, Electric Power Res. Inst., Palo A1to, CA, Report EPRI CS-2287, 1982

32. Maxwe11, E. and Kell and, D.R., High Gradient Magnetic Separation in Coal Desulphurization, IEEE Trans. Magn., MAG-14, 482, 1978

33. Dijkhuis, J.I. and Kerkdijk, C.B.W., Upgrading of Coal Using Cryogenic HGMS, IEEE Trans. Magn., MAG-17, 1503, 1981

34. Andreasen, A.H.M., The Technological Importance of the Degree of Fineness, Kem. Maanedsblad, 19, 125, 1938

35. Hise, E.C., Correlation of physical coal separation, Oak Ridge National Lab., ORNL-5570, 1979

36. Hise, E.C., Wechsler, I. and Doulin, J.M., Separation of dry crushed coals by high gradient magnetic separation, Oak Ridge National Lab., ORNL-5571, 1979 
37. Hise, E.C., Wechsler, I. and Doulin, H.M., Continuous separation of dry crushed coal at one ton per hour by high gradient magnetic separation. Oak Ridge National Lab., ORNL-5763, 1981

38. Lui, Y.A., Wagner, R.G., McCord, T.H. and Norwood, D.W., A Novel Superconducting Fluidized Bed HGMS Process for Desulphurization of Dry Pulverized Coals for Utility Applications, IEEE Trans. Magn., MAG-16, 940, 1980

39. Dörr, H., Monostony, F.P. and Siede, M., Desulphurization of Solid Fuels in Power Stations by Superconductive Magnets, Gluckauf, 117, 11, 1981

40. Cohen, E. and Good, J.A., The Application of a Superconducting Magnet System to the Cleaning and Desulphurization of Coal, IEEE Trans. Magn., MAG-12, 1, 1976

41. Cohen, E. and Good, J.A., Principles, design and performance of a superconducting magnet system for mineral separation in magnetic fields of high intensity. 11th Min. Proc. Conf., Cagliari, paper 28, 1975

42. Hise, E.C., Development of High Gradient and Open Gradient Magnetic Separation, IEEE Trans. Magn., MAG-18, 847, 1982

43. Magadeesh, M.S. and Seehra, M.S., Thermomagnetic Studies of Conversion of Pyrite and Marcasite in Different Atmospheres (vacuum, $\mathrm{H}_{2}$, He and $\mathrm{CO}$ ), J. Phys. D: App. Phys., 14, 2153, 1981

44. Marusak, L.A., Walker, P.L. and Mulay, L.N., The Microkinetics of the Oxidation of Pyrite, IEEE Trans. Magn., MAG-12, 889, 1976

45. Fanslow, G.E., Bluhm, D.D. and Nelson, S.O., Dielectric heating in mixtures containing coal and pyrite, Ames Lab., Iowa State Univ., US/DOE/IS-4738, 1980

46. Hazen Research Inc., Process for improving coal, U.S. Patent 3938966, Feb., 1976

47. Oder, R.R., Magnetic Desulphurization of Liquefied Coals: Conceptual Process Design and Cost Estimates, IEEE Trans. Magn., MAG-12, 532, 1976

48. Jacobs, I.S. and Levinson, L.M., Solvent Refining of Wyodak, Illinois No. 6 and Black Mesa Coals, Electric Power Res. Inst., Palo Alto, CA, Report EPRI RP389, Vol. 2, 1976

49. Maxwe11, E., Magnetic Separation of Mineral Matter from Coal Liquids, Electric Power Res. Inst., Palo Alto, CA, Report $\overline{\mathrm{AF}-508,} 1977$ 


\section{MANUSCRIPT RECEIVED}

'The Magnetic Beneficiation of Coal'

S.E. Male

(manuscript received 15 September, 1984;

revised form 20 February, 1985). 